\title{
Obesity accelerates T cell senescence in murine visceral adipose tissue
}

\author{
Kohsuke Shirakawa, ${ }^{1}$ Xiaoxiang Yan, ${ }^{1,2}$ Ken Shinmura, ${ }^{3}$ Jin Endo, ${ }^{1}$ Masaharu Kataoka, ${ }^{1}$ Yoshinori Katsumata, ${ }^{1}$ \\ Tsunehisa Yamamoto, ${ }^{1}$ Atsushi Anzai, ${ }^{1}$ Sarasa Isobe, ${ }^{1}$ Naohiro Yoshida, ${ }^{1,4}$ Hiroshi Itoh, ${ }^{5}$ Ichiro Manabe, ${ }^{6}$ Miho Sekai, ${ }^{7}$ \\ Yoko Hamazaki, Keiichi Fukuda, ${ }^{7}$ Nagahiro Minato, ${ }^{7}$ and Motoaki Sano ${ }^{1,8}$
}

\begin{abstract}
'Department of Cardiology, Keio University School of Medicine, Tokyo, Japan. '2Department of Cardiology, Ruijin Hospital, Shanghai Jiaotong University School of Medicine, Shanghai, China. ${ }^{3}$ Department of General Medicine, Hyogo College of Medicine, Hyogo, Japan. ${ }^{4}$ Department of Endocrinology and Hypertension, Tokyo Women's Medical University, Tokyo, Japan. ${ }^{5}$ Department of Endocrinology, Metabolism and Nephrology, Keio University School of Medicine, Tokyo, Japan. Department of Cardiovascular Medicine, Graduate School of Medicine, The University of Tokyo, Tokyo, Japan. ${ }^{7}$ Department of Immunology and Cell Biology, Graduate School of Medicine, Kyoto University, Kyoto, Japan. ${ }^{8}$ Precursory Research for Embryonic Science and Technology (PREST), Japan Science and Technology (JST) Agency, Tokyo, Japan.
\end{abstract}

\begin{abstract}
Chronic inflammation in visceral adipose tissue (VAT) precipitates the development of cardiometabolic disorders. Although changes in T cell function associated with visceral obesity are thought to affect chronic VAT inflammation, the specific features of these changes remain elusive. Here, we have determined that a high-fat diet (HFD) caused a preferential increase and accumulation of $\mathrm{CD} 44^{\text {hi }} \mathrm{CD} 2 \mathrm{~L}^{\circ}{ }^{\circ} \mathrm{CD} 4^{+} \mathrm{T}$ cells that constitutively express PD-1 and CD153 in a B cell-dependent manner in VAT. These cells possessed characteristics of cellular senescence and showed a strong activation of Spp1 (encoding osteopontin [OPN]) in VAT. Upon T cell receptor stimulation, these T cells also produced large amounts of OPN in a PD-1resistant manner in vitro. The features of $\mathrm{CD} 153^{+} \mathrm{PD}-1^{+} \mathrm{CD} 44^{\text {hi }} \mathrm{CD} 4^{+} \mathrm{T}$ cells were highly reminiscent of senescence-associated CD4 ${ }^{+} \mathrm{T}$ cells that normally increase with age. Adoptive transfer of CD153+PD-1+CD44 ${ }^{\text {hic }} 4^{+} \mathrm{T}$ cells from HFD-fed WT, but not Spp1-deficient, mice into the VAT of lean mice fed a normal diet recapitulated the essential features of VAT inflammation and insulin resistance. Our results demonstrate that a distinct $C D 153^{+} \mathrm{PD}-1^{+} \mathrm{CD} 44^{\text {hic }} \mathrm{CD} 4^{+} \mathrm{T}$ cell population that accumulates in the VAT of HFD-fed obese mice causes VAT inflammation by producing large amounts of OPN. This finding suggests a link between visceral adiposity and immune aging.
\end{abstract}

\section{Introduction}

Visceral obesity is associated with chronic low-grade inflammation in visceral adipose tissue (VAT) and a sustained whole-body proinflammatory state, which may underlie metabolic and cardiovascular diseases (1-6). VAT inflammation associated with obesity involves a complex network of responses of immune cell components, including acquired immune cells such as various subsets of $\mathrm{T}$ cells and $\mathrm{B}$ cells and innate immune cells such as macrophages (7-10). Among these cells, $\mathrm{CD}^{+} \mathrm{T}$ cells have been recognized as a central regulator of chronic VAT inflammation (9-14). The number of $\mathrm{CD} 4^{+} \mathrm{T}$ cells in VAT increases as the tissue expands in obesity. Factors that drive $\mathrm{CD} 4^{+} \mathrm{T}$ cell expansion and differentiation into proinflammatory effectors in VAT during the development of high-fat diet-induced (HFD-induced) obesity may include MHC class II-associated antigens, possibly self-peptides, because the T cell receptor (TCR) repertoire of $\mathrm{CD} 4^{+} \mathrm{T}$ cells in VAT is limited, and deficiency of MHC class II protects mice from HFD-induced VAT inflammation and insulin resistance $(11,14-16)$. For instance, IFN- $\gamma$-producing Th1 cells enhance proinflammatory macrophage activation $(12-14,17)$, and IL-17 produced by Th17 cells may

Authorship note: K. Shirakawa and X. Yan contributed equally to this work. Conflict of interest: The authors have declared that no conflict of interest exists. Submitted: May 16, 2016; Accepted: September 29, 2016.

Reference information: / Clin Invest. 2016;126(12):4626-4639. doi:10.1172/JCI88606. cause insulin resistance by affecting insulin receptor signaling (18). By contrast, IL-4- and IL-13-secreting Th2 cells and FoxP3 ${ }^{+}$ Tregs suppress VAT inflammation by inducing antiinflammatory macrophages that secrete IL-10 (19-21). However, the obesityassociated immune background underlying chronic inflammation in VAT remains elusive.

Significant changes occur in the overall $\mathrm{T}$ cell populations with age. In $\mathrm{CD} 4^{+} \mathrm{T}$ cells, proportions of naive $\left(\mathrm{CD} 44^{\mathrm{lo}} \mathrm{CD} 62 \mathrm{~L}^{\mathrm{hi}}\right)$ cells sharply decline in ontogeny, with an age-dependent increase in cells of the memory phenotype $\left(\mathrm{CD} 44^{\mathrm{hi}} \mathrm{CD} 62 \mathrm{~L}^{\mathrm{lo}}\right)(22,23)$. Among $\mathrm{CD} 44^{\mathrm{hi}} \mathrm{CD} 4^{+} \mathrm{T}$ cells, a unique population expressing programmed cell death 1 (PD-1) and CD153 actually increases with age in mice (20). PD-1 is a negative costimulatory receptor for TCR signaling (24), and CD153 is a TNF superfamily protein (25). The $\mathrm{CD} 153^{+} \mathrm{PD}-1^{+} \mathrm{CD} 44^{\text {hi }} \mathrm{CD} 4^{+} \mathrm{T}$ cell population shows compromised proliferation and regular $\mathrm{T}$ cell cytokine production on $\mathrm{T}$ cell receptor (TCR) stimulation but secretes large amounts of proinflammatory cytokines, such as osteopontin (OPN). These $\mathrm{CD} 4^{+} \mathrm{T}$ cells also show signatures of cell senescence, including a marked increase in senescence-related gene expression and nuclear heterochromatin foci, and are termed senescence-associated $\mathrm{T}$ cells (SA-T cells) (9). Notably, the age-dependent development of SA-T cells, which may include autoreactive cells, is dependent on B cells (9). As such, the increase in SA-T cells is suggested to be involved in part in immune aging phenotypes such as impaired acquired 
A

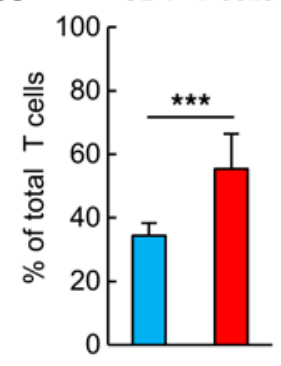

$\mathrm{CD}^{+} \mathrm{T}$ cells

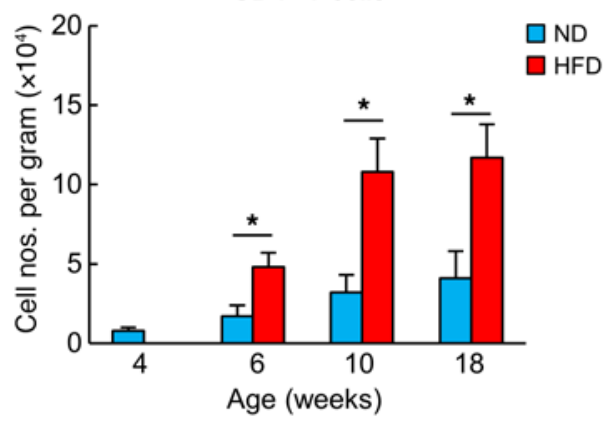

B

$\mathrm{CD}^{+} \mathrm{T}$ cells
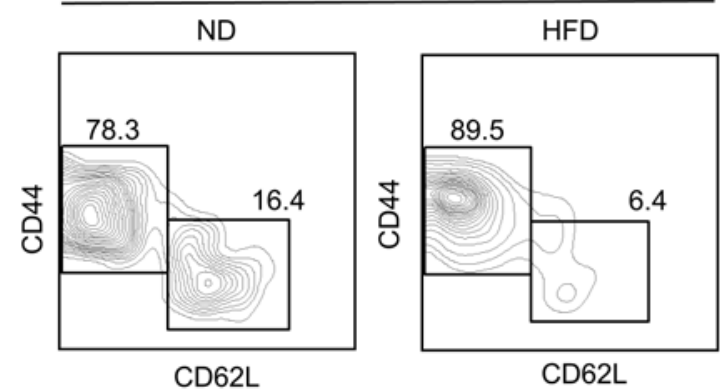

$\mathrm{CD} 44^{10} \mathrm{CD} 62 \mathrm{~L}^{\mathrm{hi}}$

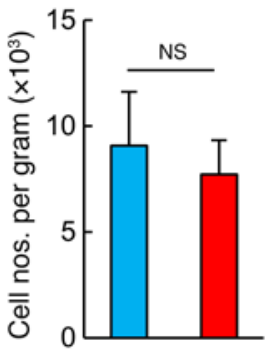

CD44 ${ }^{\text {niCD62L }}{ }^{\text {lo }}$

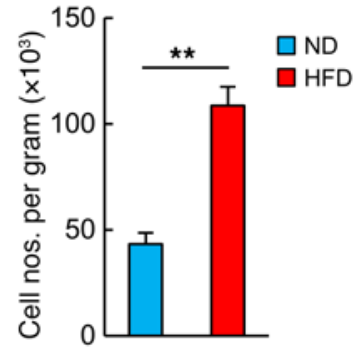

Figure 1. An HFD induces the accumulation of CD44 ${ }^{\text {hi } C D 4^{+}}$T cells in VAT. WT mice were fed an HFD for 14 weeks beginning at 4 weeks of age. Agematched WT mice fed an ND were used as controls. (A) Proportion of VAT CD4+ T cells in total T cells. Temporal dynamics of changes in the number of CD4+

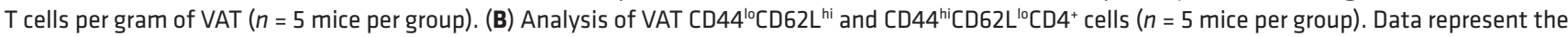
mean \pm SEM. ${ }^{*} P<0.05,{ }^{*} P<0.001$, and ${ }^{* * *} P<0.0001$, by 2 -tailed Student's $t$ test.

immune capacity, increased proinflammatory traits, and high risk for autoimmunity (26).

In the present study, we demonstrate that $\mathrm{CD} 153^{+} \mathrm{PD}-1^{+}$ $\mathrm{CD} 44^{\mathrm{hi}} \mathrm{CD} 4^{+} \mathrm{T}$ cells are remarkably increased and preferentially accumulated in the VAT of HFD-fed mice in a B cell-dependent manner and that these $\mathrm{CD} 4^{+} \mathrm{T}$ cells show functional and genetic features strongly resembling SA-T cells that increase in secondary lymphoid tissues with age. We also indicate that the $\mathrm{CD} 153^{+} \mathrm{PD}-1^{+} \mathrm{CD} 44^{\text {hi }} \mathrm{CD} 4^{+} \mathrm{T}$ cells play a crucial role in inducing chronic VAT inflammation and metabolic disorder via secretion of large amounts of OPN.

\section{Results}

A HFD induces an increase and accumulation of PD $-1^{+} C D 44^{\text {hi }} C D 62 L^{l o}$ $C D 4^{+} T$ cells in VAT. C57BL/6 (B6) mice were fed an HFD starting at 4 weeks of age. By 18 weeks of age, these mice had an increased BW and visceral fat mass, glucose intolerance, and insulin resistance compared with age-matched B6 mice fed a normal diet (ND) (Supplemental Figure 1, A and B; supplemental material available online with this article; doi:10.1172/JCI88606DS1). HFD-fed mice showed remarkably increased numbers of $\mathrm{F} 4 / 80^{+} \mathrm{CD} 11 \mathrm{~b}^{+}$ macrophages per gram of VAT, with a drastic shift from a CD11 ${ }^{\text {lo }}$ CD206 ${ }^{\text {hi }}$ to a CD11c ${ }^{\text {hi }} C D 206^{\text {lo }}$ phenotype (Supplemental Figure $1, C$ and D). These macrophages were localized in crown-like structures (CLSs) (Supplemental Figure 1E), representing typical obesity-associated chronic inflammation of VAT $(17,27)$. VAT of 18-week-old HFD-fed obese mice showed increased proportions of $\mathrm{CD}^{+} \mathrm{T}$ cells in total $\mathrm{T}$ cell infiltrates (Figure $1 \mathrm{~A}$ ). The absolute numbers of $\mathrm{CD}^{+} \mathrm{T}$ cells per gram of VAT were significantly high- er than those in ND-fed mice as early as 2 weeks after initiation of the HFD and progressively increased thereafter (Figure 1A). Notably, the VAT CD4 ${ }^{+}$T cells from 18 -week-old HFD-fed mice showed an increasing shift in the proportions of naive $\mathrm{CD} 44^{\text {lo }}$ CD62 $\mathrm{L}^{\text {hi }}$ to $\mathrm{CD} 44^{\text {hi }}{ }^{\mathrm{CD}} 62 \mathrm{~L}^{\text {lo }}$ phenotype $\mathrm{T}$ cells (Figure $1 \mathrm{~B}$ ), and the increase in absolute numbers of VAT CD $4^{+} \mathrm{T}$ cells was largely attributed to the $\mathrm{CD} 44^{\mathrm{hi}} \mathrm{CD} 62 \mathrm{~L}^{\text {lo }}$ cells (Figure 1B). More than half of the VAT CD $44^{\text {hi }} \mathrm{CD} 44^{+} \mathrm{T}$ cells expressed PD-1, and the numbers of $\mathrm{PD}-1^{+} \mathrm{CD} 44^{\text {hi }} \mathrm{CD} 4^{+} \mathrm{T}$ cells were remarkably higher than those in age-matched ND-fed mice (Figure 2A). Immunostaining analysis confirmed that PD-1+ $1^{+}$cells were localized in CLSs of HFD-fed obese mice, but they were rarely detected in those of ND-fed lean mice (Figures 2B). These results indicate that PD $-1^{+} \mathrm{CD} 44^{\mathrm{hi}} \mathrm{CD} 4^{+}$ $\mathrm{T}$ cells are predominantly increased in the inflammatory foci of VAT from HFD-fed mice.

The VAT PD $-1^{+} C D 44^{h i} C D 4^{+} T$ cell population includes senescent $T$ cells that preferentially produce OPN. We next compared the functional features of PD $-1^{+}$and PD $-1^{-} \mathrm{CD} 4^{+}$T cells in VAT from 18 -weekold HFD-fed mice. Isolated PD $-1^{+} \mathrm{CD} 44^{\text {hi }} \mathrm{CD} 4^{+} \mathrm{T}$ cells showed significantly less production of IL-2 and IFN- $\gamma$ upon TCR stimulation than did PD $-1^{-} \mathrm{CD} 4^{+}$cells (Figure $3 \mathrm{~A}$ ), which was consistent with diminished expression of special AT-rich sequence-binding protein 1 (Satb1), a crucial gene for T cell cytokine activation $(28,29)$, and increased expression of CCAAT/enhancer-binding protein $\alpha$ (Cebpa), which is normally expressed in myeloid cell lineages (30) (Figure $3 \mathrm{~B})$. However, the VAT PD $-1^{+} \mathrm{CD} 44^{\mathrm{hi}} \mathrm{CD} 4^{+} \mathrm{T}$ cells secreted remarkably large amounts of OPN via TCR stimulation, whereas the PD-1- fraction did so minimally (Figure 3C). HFD-fed mice consistently showed significantly increased serum OPN levels (Figure 
A

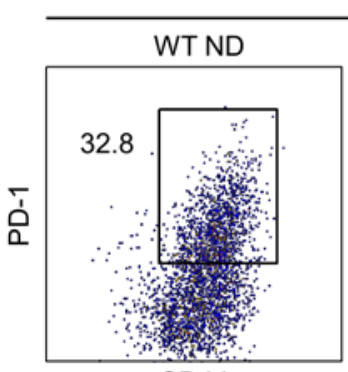

CD44

B
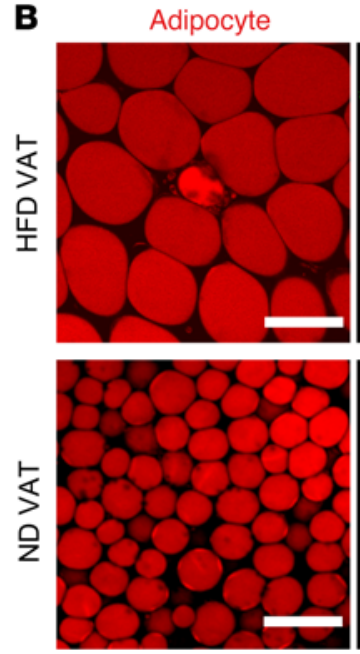

$\mathrm{CD}^{+} \mathrm{T}$ cells

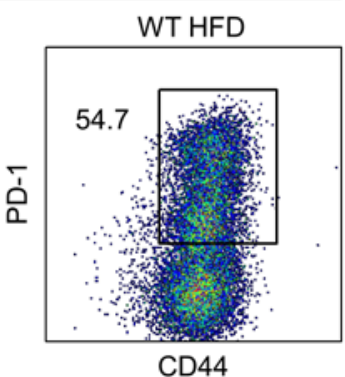

$\mathrm{PD}-1^{+} \mathrm{T}$ cells

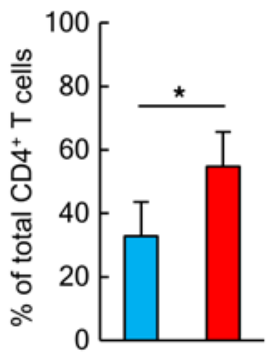

$\mathrm{PD}-1^{+} \mathrm{T}$ cells

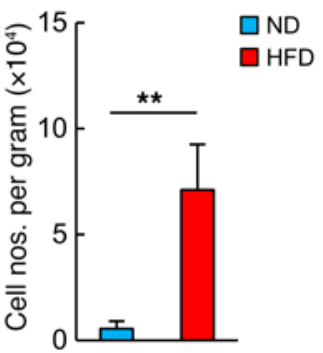

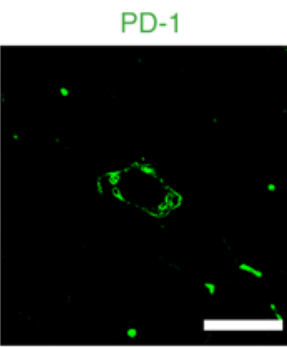
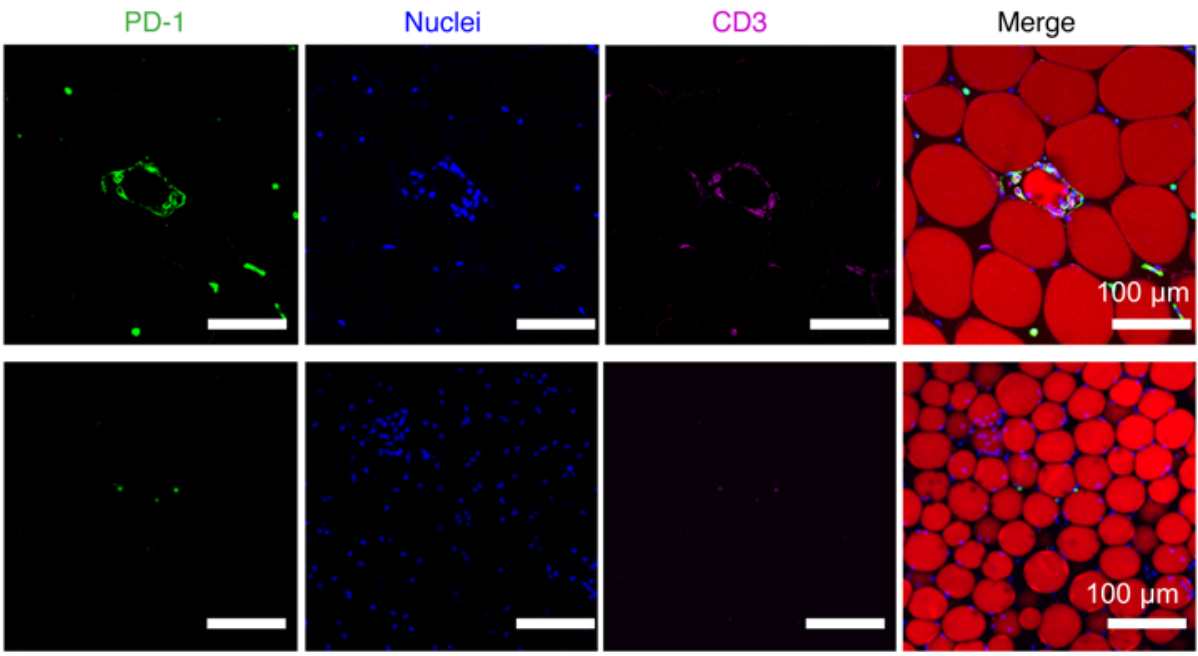

Figure 2. An HFD induces the accumulation of PD-1+CD44 ${ }^{\text {hi } C D 4}{ }^{+}$T cells in VAT. WT mice were fed an HFD for 14 weeks beginning at 4 weeks of age. Agematched WT mice fed an ND were used as controls. (A) Analysis of VAT PD- $1^{+}$CD44 $4^{\text {hiCD }} 4^{+}$cells ( $n=5-6$ mice per group). Data represent the mean \pm SEM. ${ }^{*} P<0.05$ and ${ }^{*} P<0.001$, by 2 -tailed Student's $t$ test. (B) Histological analyses of VAT. Adipocytes (BODIPY, red), PD-1 (yellow), nuclei (DAPI, blue), and CD3 (pink). Scale bars: $100 \mu \mathrm{m}$.

3D). Furthermore, the vast majority of the PD-1+ cells expressed senescence-associated $\beta$-galactosidase (SA- $\beta$-gal), a typical cell senescence marker (Figure $3 \mathrm{E}$ ), and showed remarkably higher expression of $\gamma-\mathrm{H} 2 \mathrm{AX}$ compared with the $\mathrm{PD}-1^{-}$counterpart cells (Figure 3F), which is indicative of greater exposure to genostress. These findings suggest that the $\mathrm{CD} 44^{\mathrm{hi}} \mathrm{CD} 4^{+} \mathrm{T}$ cell population in VAT of HFD-fed mice includes senescent $\mathrm{T}$ cells capable of preferentially producing OPN.

CD153 expression defines a unique $P D-1^{+} C D 44^{\text {hi }} C D 4^{+}$T cell population with features of cell senescence that increases almost exclusively in VAT of HFD-fed mice. Because CD153 expression defines the SA-T cells, which gradually increase systemically with age (31), we next examined the expression of CD153 in VAT. We found that a minor population of VAT PD $-1^{+} \mathrm{CD} 4^{+} \mathrm{T}$ cells in HFD-induced obese mice strongly expressed CD153 (approximately $15 \%$ of $\mathrm{CD} 4^{+} \mathrm{T}$ cells), whereas $\mathrm{CD} 4^{+} \mathrm{T}$ cells in VAT of ND-fed mice rarely did so (Figure $4 \mathrm{~A})$. Other infiltrated cell populations such as $\mathrm{CD} 8^{+}$ $\mathrm{T}$ cells, macrophages, and $\mathrm{B}$ cells in VAT of HFD-fed mice hardly expressed CD153 (Figure 4B). The CD $153^{+} \mathrm{PD}-1^{+} \mathrm{CD} 44^{\mathrm{hi}} \mathrm{CD} 4^{+}$ $\mathrm{T}$ cells were evident in VAT beginning 2 weeks after initiation of the HFD and dramatically increased in mice at 18 weeks of age, thus becoming prominent at later stages in the $\mathrm{PD}-1^{+} \mathrm{CD} 44^{\mathrm{hi}} \mathrm{CD} 4^{+}$ $\mathrm{T}$ cells (Figure 4C; see also Figure $2 \mathrm{~A}$ ). In contrast, this cell population remained negligible in VAT from ND-fed mice at least until 18 weeks of age (Figure $4 \mathrm{C}$ ). We then isolated 3 distinct populations of CD $4^{+}$T cells, PD $-1^{-}, \mathrm{CD} 153^{-} \mathrm{PD}-1^{+}$, and CD $153^{+} \mathrm{PD}-1^{+}$, from VAT of 18-week-old HFD-fed obese mice and compared their genetic signatures. Expression of secreted phosphoprotein 1 (Spp1), encoding OPN, was markedly high in the $\mathrm{CD} 153^{+}$cells, whereas its expression was minimal in $\mathrm{CD} 153^{-} \mathrm{PD}-1^{+}$and $\mathrm{PD}-1^{-}$cells (Figure $5 \mathrm{~A}) . \mathrm{CD} 153^{+}$cells also showed significantly increased expression of cyclin-dependent kinase inhibitor 1A (Cdkn1a, also known as Cip1) and Cdkn2b (also known as Ink4b), which are typical cellular senescence biomarker genes (32), compared with CD153-PD-1 ${ }^{+}$ and PD-1 $1^{-}$cells. Both $\mathrm{CD} 153^{+}$and $\mathrm{CD} 153^{-} \mathrm{PD}-1^{+}$cells showed downregulation of Satb1, eukaryotic translation elongation factor $1 \alpha 1$ (Eef1a1), and dual-specificity phosphatase 10 (Dusp10) expression, also suggestive of cellular senescence $(33,34)$. Further, the vast majority of $\mathrm{CD} 153^{+} \mathrm{PD}-1^{+}$cells expressed SA- $\beta$-gal (Figure 5B) and showed the highest expression of $\gamma$-H2AX among the subpopulations (Figure 5C). In 18-week-old HFD-fed mice, $\mathrm{CD} 153^{+} \mathrm{PD}-1^{+} \mathrm{CD} 4^{+} \mathrm{T}$ cells predominantly accumulated in VAT, although they also appeared in much lower numbers in spleen, liver, and subcutaneous adipose tissue (SAT) and negligibly in blood (Figure 5D). In VAT, CD153 ${ }^{+} \mathrm{T}$ cells were confirmed to be localized in CLSs (Figure 5E). These results indicated that CD $153^{+} \mathrm{PD}-1^{+}$ $\mathrm{CD} 44^{\mathrm{hi}} \mathrm{CD} 4^{+} \mathrm{T}$ cells with features of cell senescence were specifically increased and accumulated in VAT of HFD-fed mice. 
A
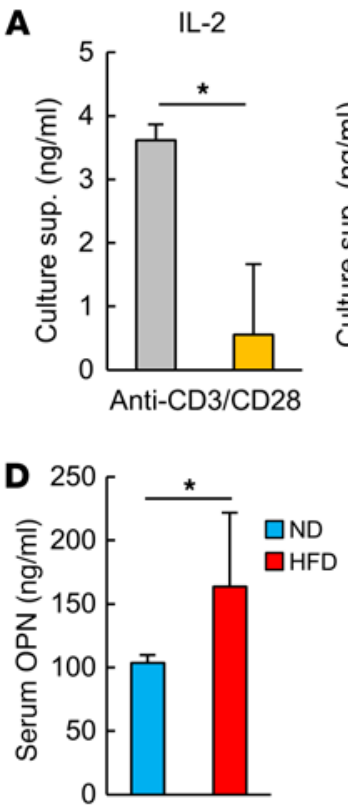
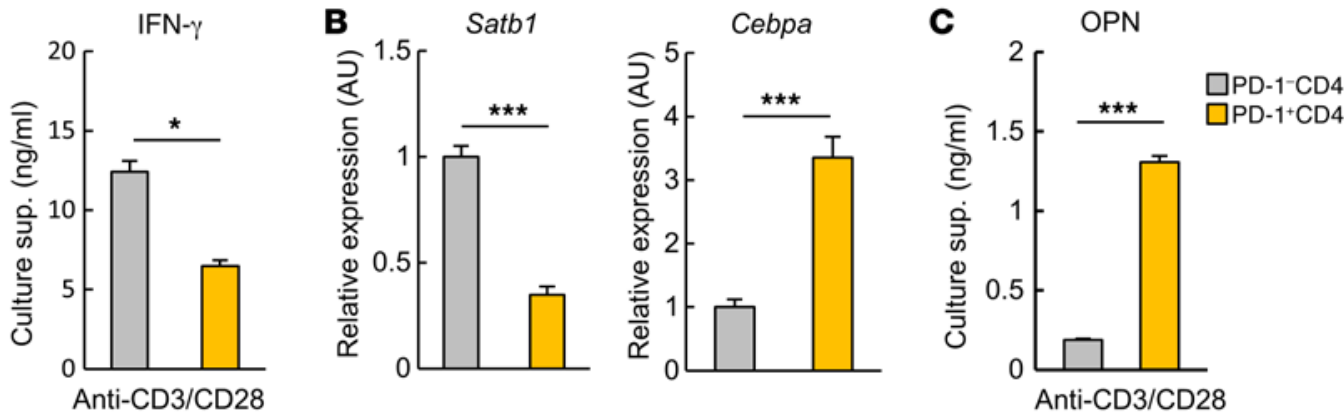
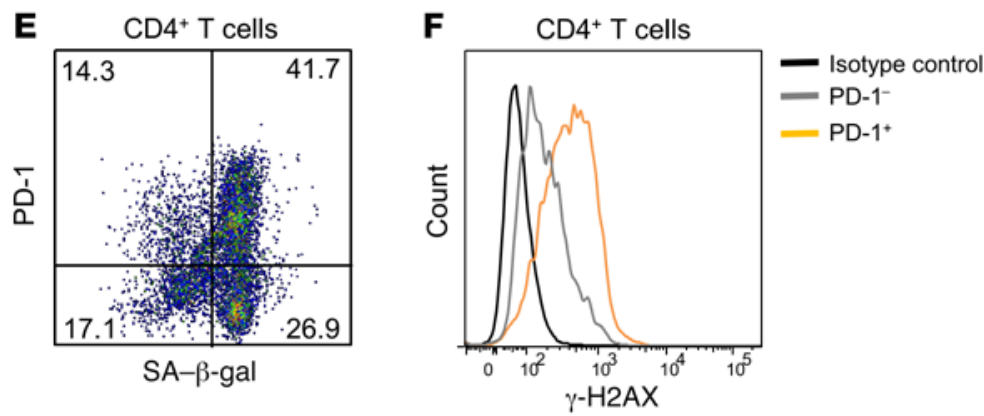

Figure 3. Adipose PD-1+CD4+ $T$ cells secrete a large amount of OPN at the cost of normal function. $\mathrm{PD}-1^{+}$and $\mathrm{PD}-1^{-} \mathrm{CD} 4^{+} \mathrm{T}$ cells were separately isolated from VAT of 18-week-old HFD-fed mice. (A) VAT PD-1 ${ }^{+}$and PD-1-CD4+ $T$ cells were cultured in the presence or absence of anti-CD3 and anti-CD28 mAb for 3 days. IL-2 and IFN- $\gamma$ in the culture supernatants (sup.) were assessed on day 3 by ELISA ( $n=3$ mice per group). (B) VAT PD- $1^{+}$and PD-1-CD4 ${ }^{+}$T cells were analyzed for Satb1 and Cebpa mRNA expression by real-time PCR ( $n=5$ mice per group). (C) VAT PD-1+ and PD-1-CD4+ ${ }^{+}$cells were cultured in the presence or absence of anti-CD3 and anti-CD28 mAb for 3 days. OPN in the culture supernatants was assessed on day 3 by ELISA ( $n=3$ mice per group). (D) Serum OPN levels in mice fed an ND or HFD for 14 weeks ( $n=5$ mice per group). (E) Representative flow cytometric analysis demonstrating SA- $\beta$-gal activity. (F) Representative flow cytometric analysis demonstrating the phosphorylated histone $\mathrm{H} 2 \mathrm{AX}$ at serine 139 (referred to as $\gamma-\mathrm{H} 2 \mathrm{AX}$ ) of VAT CD4 ${ }^{+}$T cells. Flow cytometric plots are representative of at least 3 independent experiments. Data represent the mean \pm SEM. ${ }^{*} P<0.05$ and ${ }^{* * *} P<0.0001$, by 2 -tailed Student's $t$ test.

$C D 153^{+} \mathrm{PD}-1^{+} \mathrm{CD} 4^{+} \mathrm{T}$ cells are the main source of OPN in VAT of HFD-fed mice. CD $153^{+} \mathrm{PD}-1^{+} \mathrm{CD} 4^{+} \mathrm{T}$ cells in VAT barely expressed FoxP3, GATA3, or ROR $\gamma$ t, but markedly expressed T-bet (Figure 6A), which suggests that these $\mathrm{T}$ cells may belong to a Th1 cell lineage. Consistent with this finding, these cells secreted IFN- $\gamma$ upon TCR stimulation, although the level was significantly lower than that detected in the $\mathrm{PD}-1^{-} \mathrm{CD} 4^{+} \mathrm{T}$ cell population (Figure $6 \mathrm{~B}$ ). However, only $\mathrm{CD} 153^{+} \mathrm{PD}-1^{+} \mathrm{CD} 4^{+} \mathrm{T}$ cells secreted small yet significant amounts of OPN, even in the absence of TCR stimulation, and the secretion was markedly enhanced through TCR stimulation (Figure $6 \mathrm{~B})$. The $\mathrm{PD}-1^{-} \mathrm{CD} 4^{+} \mathrm{T}$ cell population only minimally produced OPN, even after TCR stimulation (Figure 6B), suggesting that the potent $\mathrm{OPN}$ production by $\mathrm{CD} 153^{+} \mathrm{PD}-1^{+} \mathrm{CD} 4^{+} \mathrm{T}$ cells in VAT may not be a mere reflection of the nature of the Th1 cells. To further validate whether these T cells can indeed produce OPN in situ in the VAT of HFD-fed obese mice, we used 18-week-old EGFP-Spp1 knockin (KI) reporter mice fed an HFD on the same schedule. Among CD4 ${ }^{+}$T cells in VAT, GFP (namely, the activity of Spp1 gene transcription in situ) was expressed almost exclusively in the PD- $1^{+}$cell population (Figure $6 \mathrm{C}$, left). A detailed analysis revealed that GFP expression was largely confined to the PD- $1^{\text {hi }}$ population, in which the GFP expression level was well correlated with that of CD153; PD-1 ${ }^{\text {lo }}$ and PD-1 ${ }^{\text {null }}$ cells expressed minimal and negligible CD153 and GFP, respectively (Figure 6C, right, and Figure 6D). Expression of GFP was undetectable in CD8 ${ }^{+}$ $\mathrm{T}$ cells and low in B cells in VAT (Figure 6E). Although macrophages have long been regarded as a source of OPN, expression of GFP was modest in VAT (Figure 6E). Thus, these results suggest that $S p p 1$ gene activation is strongly induced in a proportion of $\mathrm{CD} 153^{+} \mathrm{PD}-1^{+} \mathrm{CD} 4^{+} \mathrm{T}$ cells in VAT in an unsynchronized manner over a given time period, whereas the $S p p 1$ gene may be activated constitutively to a much lesser extent in VAT macrophages. The PD-1 receptor plays an important role in resolving inflammation by negatively regulating $\mathrm{T}$ cell activation upon interaction with the ligands (35-38). We found that adipocytes, macrophages, and B cells, the major antigen-presenting cells in VAT $(11,16,39)$, strongly expressed programmed cell death ligand 1 (PD-L1) in HFD-fed mice (Figure 7A). However, although stimulation with solid-phase PD-L-Ig fusion protein significantly suppressed IFN- $\gamma$ production by $\mathrm{CD} 153^{+} \mathrm{PD}-1^{+} \mathrm{CD} 4^{+} \mathrm{T}$ cells upon TCR stimulation in vitro, it did not at all affect OPN production by the same cell population (Figure $7 \mathrm{~B})$. These results suggest that $\mathrm{CD} 153^{+} \mathrm{PD}-1^{+} \mathrm{CD} 4^{+} \mathrm{T}$ cells are the main source of OPN in VAT of HFD-fed obese mice, in which these T cells are capable of secreting abundant OPN in a manner resistant to negative signaling via $\mathrm{PD}-1$.

$C D 153^{+} P D-1^{+} C D 4^{+} T$ cells induce VAT inflammation and insulin resistance upon cell transfer. To directly examine the possible pathogenic role of $\mathrm{CD} 153^{+} \mathrm{PD}-1^{+} \mathrm{CD} 4^{+} \mathrm{T}$ cells in VAT inflammation, we performed adoptive transfer of 3 distinct subsets of $\mathrm{CD} 4^{+} \mathrm{T}$ cells into the VAT of ND-fed lean mice. Since very limited numbers of these cells were obtained after sorting from the VAT, we used splenic $\mathrm{CD} 4^{+} \mathrm{T}$ cell counterpart populations from 18-week-old HFD-fed obese mice. We confirmed that isolated PD-1- ${ }^{-}$CD $153^{-} \mathrm{PD}-1^{+}$, and $\mathrm{CD} 153^{+} \mathrm{PD}-1^{+} \mathrm{CD} 4^{+} \mathrm{T}$ cells from spleens exhibited features that 
A

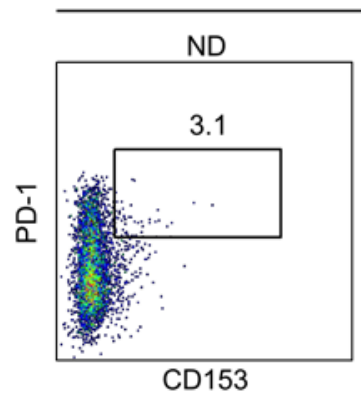

B

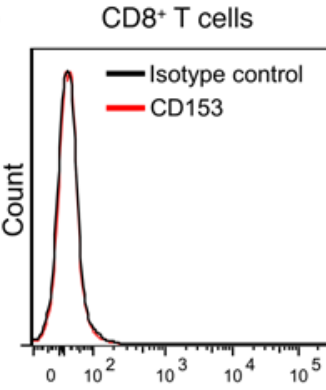

$\mathrm{CD}^{+} \mathrm{T}$ cells

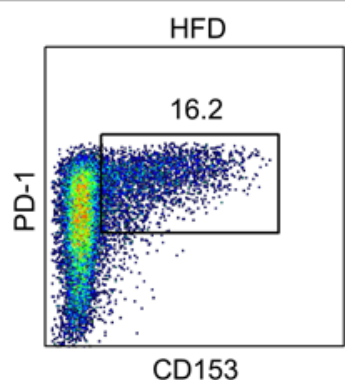

CD153

\section{CD153+PD-1+ cells}
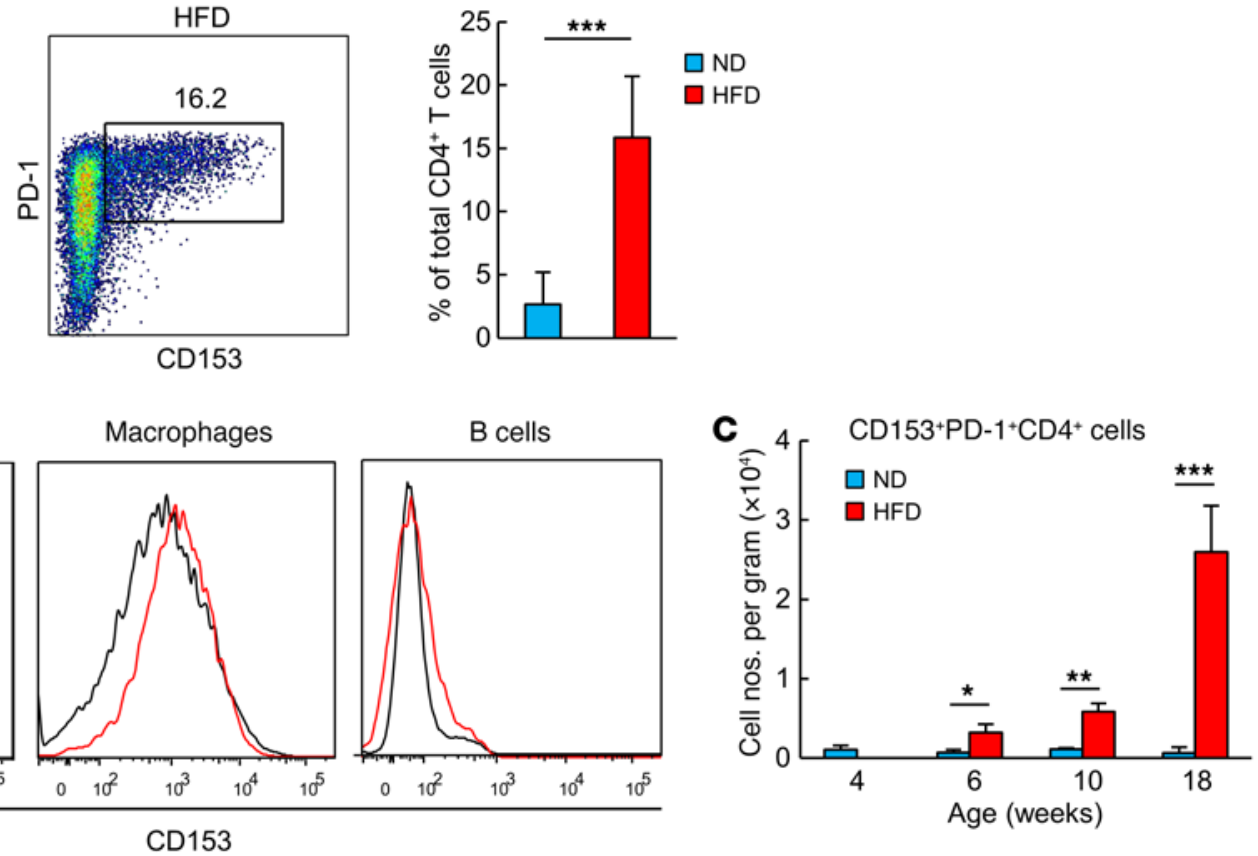

Figure 4. CD153+PD-1+CD4 T cells increase almost exclusively in the VAT of HFD-fed mice. (A) Analysis of VAT CD153 $3^{+} \mathrm{PD}-1^{+} \mathrm{CD} 4^{+} \mathrm{T}$ cells isolated from WT mice after 14 weeks on an ND or HFD ( $n=7$ mice per group). (B) Flow cytometric analysis of CD153 expression on CD8 ${ }^{+} T$ cells, macrophages, and B cells. (C) Temporal dynamics of changes in CD153+PD-1+CD4+ $\mathrm{T}$ cells after an HFD ( $n=5$ mice per group). Flow cytometric plots are representative of at least 3 independent experiments. Data represent the mean $\pm \mathrm{SEM}$. ${ }^{*} P<0.05$, ${ }^{* *} P<0.001$, and ${ }^{* * *} P<0.0001$, by 2 -tailed Student's $t$ test.

were essentially comparable to those from VAT (Supplemental Figure 2, A-C). Our analysis of splenic cells from HFD-fed EGFPSpp1-KI reporter mice demonstrated that a substantial portion of $\mathrm{CD} 153^{+} \mathrm{PD}-1^{+} \mathrm{CD} 4^{+} \mathrm{T}$ cells expressed GFP signal at a much higher level (about 2 logs) than did macrophages (Supplemental Figure 2, $\mathrm{D}-\mathrm{F})$. Sorted $\mathrm{CD} 4^{+} \mathrm{T}$ cell subpopulations were mixed with a solution containing a thermoreversible gelation polymer (40) to avoid mechanical cell leakage and transferred directly into the VAT of ND-fed lean mice at $1 \times 10^{5}$ cells per mouse under echographic guidance, 3 times per week for 2 weeks, starting at 18 weeks of age. Recipients injected with vehicle alone served as a control group. Immunostaining and flow cytometric analysis confirmed the successful engraftment of injected cells in VAT, without significant leakage around the VAT or other organs, including the liver (Supplemental Figure 3, A-D). Seven days after the last cell transfer, VAT from the recipient mice was analyzed for the expression of inflammation-related and adipocyte-related gene transcripts. VAT from the recipients of $\mathrm{CD} 153^{+} \mathrm{PD}-1^{+} \mathrm{CD} 4^{+} \mathrm{T}$ cells showed significantly higher expression of Spp1, Ifng, Tnfa, and Il6 and lower expression of Adipoq and Pparg than did the recipients of $\mathrm{PD}-1^{-}$or CD $153^{-} \mathrm{PD}-1^{+} \mathrm{CD} 4^{+} \mathrm{T}$ cells (Figure $8 \mathrm{~A}$ ). Also, only the recipients of $\mathrm{CD} 153^{+} \mathrm{PD}-1^{+} \mathrm{CD} 4^{+} \mathrm{T}$ cells exhibited a significant increase in serum OPN and IgG levels compared with control mice (Figure $8 \mathrm{~B})$. Furthermore, the recipients of $\mathrm{CD} 153^{+} \mathrm{PD}-1^{+} \mathrm{CD} 4^{+} \mathrm{T}$ cells and, to a lesser extent, those of CD153-PD $-1^{+} \mathrm{CD} 4^{+} \mathrm{T}$ cells showed an increase in the proportion of $\mathrm{CD} 11 \mathrm{c}^{\mathrm{hi}} \mathrm{CD} 206^{\text {lo }}$ macrophages relative to $\mathrm{CD} 11 \mathrm{c}^{\mathrm{lo}} \mathrm{CD} 206^{\mathrm{hi}}$ macrophages, although $\mathrm{CD} 11 \mathrm{c}^{\mathrm{lo}} \mathrm{CD} 206^{\mathrm{hi}}$ macrophages predominated in the recipients of $\mathrm{PD}-1^{-} \mathrm{CD} 4^{+}$ $\mathrm{T}$ cells, similar to what was observed in the control group (Figure
$8 C)$. The transfer of any $\mathrm{CD}^{+} \mathrm{T}$ cell subpopulation had no effect on BW, total VAT weight, or food intake (Supplemental Figure 4). However, only the recipients of CD $153^{+} \mathrm{PD}-1^{+} \mathrm{CD} 4^{+} \mathrm{T}$ cells showed significant aggravation of glucose tolerance and insulin sensitivity compared with control mice (Figures 8D). These results suggest that $\mathrm{CD} 153^{+} \mathrm{PD}-1^{+} \mathrm{CD} 44^{\mathrm{hi}} \mathrm{CD} 4^{+} \mathrm{T}$ cells are capable of inducing VAT inflammation and metabolic disorder in VAT.

OPN secreted by $C D 153^{+} P D-1^{+} C D 4^{+} T$ cells plays a crucial role in VAT inflammation. OPN is reported to affect the function of a number of cell types involved in inflammation (41-45). We confirmed that recombinant OPN enhances IFN- $\gamma$ secretion by both $\mathrm{CD}^{+}$and $\mathrm{CD}^{+}{ }^{+} \mathrm{T}$ cells and $\mathrm{IL}-17$ secretion by $\mathrm{CD} 4^{+} \mathrm{T}$ cells via TCR stimulation in culture, while it suppresses IL-10 secretion by $\mathrm{CD}^{+}{ }^{+} \mathrm{T}$ cells via TCR stimulation and LPS-stimulated B cells (Supplemental Figure 5, A-C). We then isolated PD-1 ${ }^{-}, \mathrm{CD} 153^{-} \mathrm{PD}-1^{+}$, CD $153^{+} \mathrm{PD}-1^{+}$, and $\mathrm{CD} 4^{+} \mathrm{T}$ cells from VAT of 18 -week-old HFDfed obese mice and cultured each fraction of cells with $B$ cells from normal B6 mice in the presence of anti-CD3/CD28 mAb. Among the 3 fractions, only TCR-stimulated $\mathrm{CD} 153^{+} \mathrm{PD}-1^{+} \mathrm{CD} 4^{+} \mathrm{T}$ cells significantly enhanced IgG secretion by B cells, and this secretion was completely abolished in the presence of anti-OPN Ab (Supplemental Figure 5D). An in vitro culture system has inherent difficulties in accurately reproducing true in vivo conditions, yet it shows that $\mathrm{CD} 153^{+} \mathrm{PD}-1^{+} \mathrm{CD} 4^{+} \mathrm{T}$ cells have a significantly higher capacity for helping $\mathrm{B}$ cells than do other subsets in the same optimized condition. Next, we separately isolated PD-1 $1^{-}, \mathrm{CD} 153^{-} \mathrm{PD}-1^{+}$, and CD153 ${ }^{+} \mathrm{PD}-1^{+} \mathrm{CD} 4^{+} \mathrm{T}$ cells from the VAT of WT mice fed an HFD, and these $\mathrm{T}$ cells were activated with anti-CD3/CD28 mAb for 3 days. Isolated peritoneal macrophages were plated in Boyden 


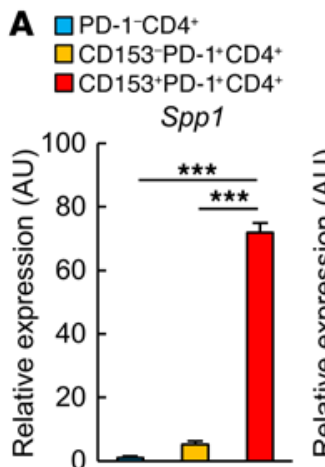

B
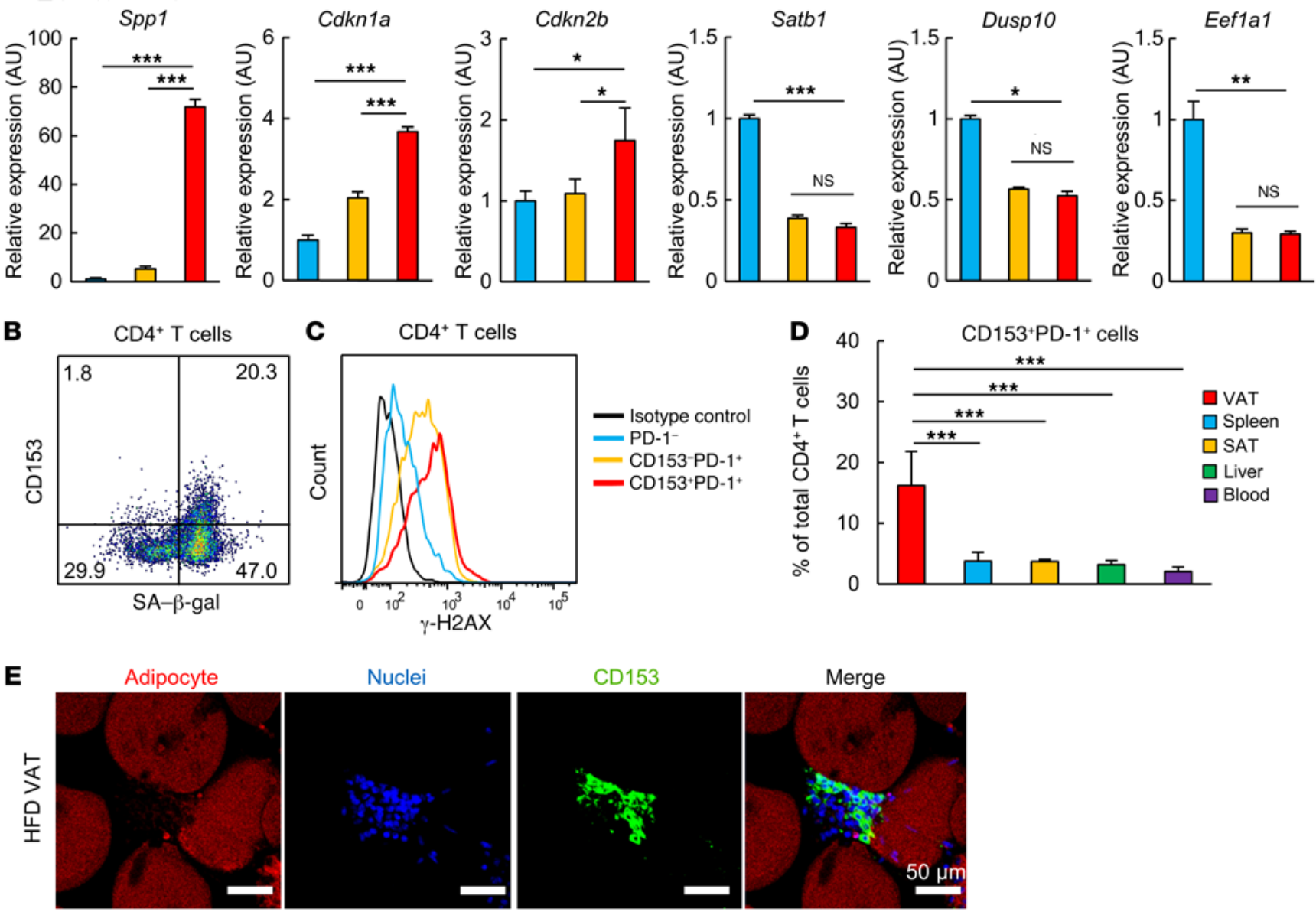

Figure 5. CD153+PD-1+ CD4 T cells have the features of cellular senescence. (A) PD-1 $1^{-}$, CD153-PD-1+, and CD153+PD-1+CD4+ $T$ cells were separately isolated from VAT of WT mice fed an HFD. Analyses of Spp1, Cdkn1a (Cip1), and Cdkn2b (Ink4b), Satb1, Dusp10, and Eef1a1 expression by real-time PCR ( $n=5$ mice per group). (B) Analyses of SA- $\beta$-gal activity ( $n=5$ mice per group). (C) Analyses of $\gamma$-H2AX expression. Data were obtained from the same sample as that for Figure 3F. (D) Localization of CD153+PD-1+CD4+ T cells in various tissues. (E) Histological analyses of VAT from WT mice after 14 weeks on an HFD. Adipocytes (BODIPY, red), CD153 (yellow), and nuclei (DAPI, blue). Scale bars: $50 \mu \mathrm{m}$. Flow cytometric plots are representative of at least 3 independent experiments. Data represent the mean $\pm \mathrm{SEM}$. ${ }^{*} P<0.05$, ${ }^{*} P<0.001$, and ${ }^{* * *} P<0.0001$, by ANOVA followed by post hoc Bonferroni tests.

chambers and treated with conditioned medium of each type of $\mathrm{CD}^{+} \mathrm{T}$ cells. Comparative analyses for the macrophage migration assay demonstrated that supernatants of $\mathrm{CD} 153^{+} \mathrm{PD}-1^{+} \mathrm{CD} 4^{+}$ $\mathrm{T}$ cells significantly enhanced macrophage migration, which was inhibited in the presence of anti-OPN Ab (Supplemental Figure $5 E)$. To further confirm the inflammatory role of OPN secreted by $\mathrm{CD} 153^{+} \mathrm{PD}-1^{+} \mathrm{CD} 4^{+} \mathrm{T}$ cells in VAT, we adoptively transferred $\mathrm{CD} 153^{+} \mathrm{PD}-1^{+} \mathrm{CD} 4^{+} \mathrm{T}$ cells isolated from the spleens of 18 -weekold HFD-fed Spp1 $1^{-/-}$and WT B6 mice into VAT of ND-fed lean B6 mice. Although VAT of the recipients of WT CD153 $3^{+} \mathrm{PD}-1^{+} \mathrm{CD} 4^{+}$ $\mathrm{T}$ cells showed significantly increased expression of the inflammatory genes Spp1, Ifng, Tnfa, and Il6 compared with expression levels in the control VAT, as before, the same $\mathrm{CD} 4^{+} \mathrm{T}$ cell fraction from $S p 1^{-/-}$mice hardly induced these effects (Figure 9A). Also, unlike WT CD153 $3^{+} \mathrm{PD}-1^{+} \mathrm{CD} 4^{+} \mathrm{T}$ cells, the transfer of $S p p 1^{1^{--}}$ $\mathrm{CD} 153^{+} \mathrm{PD}-1^{+} \mathrm{CD} 4^{+} \mathrm{T}$ cells did not affect the relative proportions of $\mathrm{CD} 11 \mathrm{c}^{\mathrm{lo}} \mathrm{CD} 206^{\mathrm{hi}}$ and $\mathrm{CD} 11 \mathrm{c}^{\mathrm{hi}} \mathrm{CD} 206^{\mathrm{lo}}$ macrophages in VAT (Figure 9B) and failed to induce an increase in OPN and IgG lev- els in serum (Figure 9C). Further, the recipients of $S p p 1^{-/-} \mathrm{CD}^{-153^{+}}$ $\mathrm{PD}-1^{+} \mathrm{CD} 4^{+} \mathrm{T}$ cells showed no significant aggravation of glucose tolerance or insulin sensitivity, unlike the recipients of WT counterpart cells (Figure 9D). These results suggest that OPN secreted from $\mathrm{CD} 153^{+} \mathrm{PD}-1^{+} \mathrm{CD} 44^{\mathrm{hi}} \mathrm{CD} 4^{+} \mathrm{T}$ cells plays a crucial role in VAT inflammation and glucose metabolism.

Robust generation of CD153 ${ }^{+} \mathrm{PD}-1^{+} C D 4^{+} T$ cells in VAT and VAT inflammation in HFD-fed obese mice partly depend on B cells. Finally, we addressed the cellular mechanisms for the accumulation and activation of VAT $\mathrm{CD} 153^{+} \mathrm{PD}-1^{+} \mathrm{CD} 4^{+} \mathrm{T}$ cells from 18-week-old HFD-fed obese mice. Because obese VAT contained a significant proportion of B cells expressing GL7, a marker of germinal center (GC) B cells (Supplemental Figure 6), we investigated the possible involvement of $\mathrm{B}$ cells in the generation of $\mathrm{CD} 153^{+} \mathrm{PD}-1^{+} \mathrm{CD} 4^{+} \mathrm{T}$ cells in VAT under HFD conditions, using $\mu \mathrm{MT}$ mice that were deficient in mature B cells. HFD-fed $\mu \mathrm{MT}$ mice showed significantly decreased proportions of $\mathrm{CD} 44^{\mathrm{hi}} \mathrm{CD} 62 \mathrm{~L}^{\mathrm{lo}} \mathrm{CD} 4^{+} \mathrm{T}$ cells (Figure $10 \mathrm{~A})$, and the effect was associated with diminished numbers of 
A
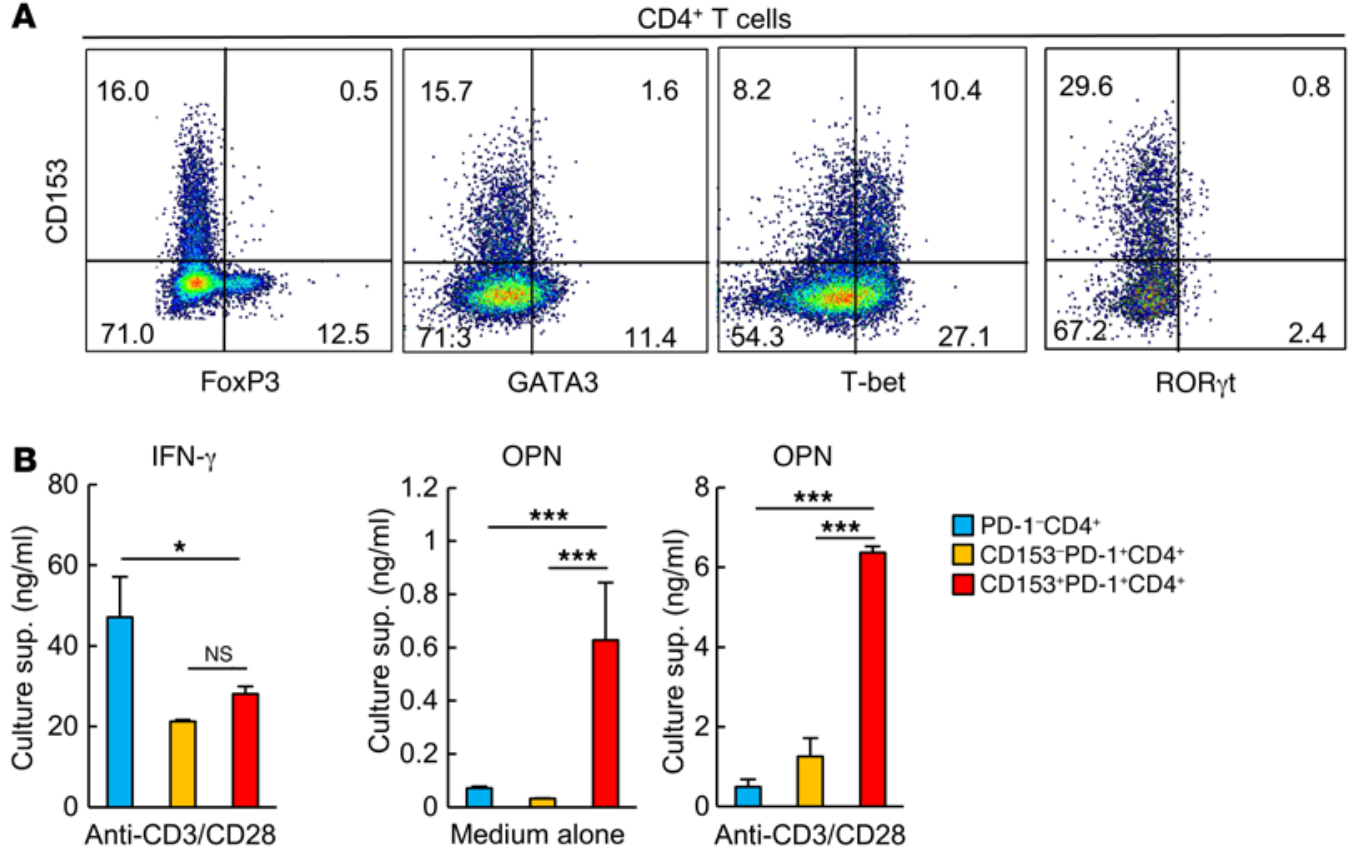

\begin{tabular}{l}
$\square \mathrm{PD}-1-\mathrm{CD}^{+}$ \\
$\square \mathrm{CD} 153-\mathrm{PD}-1+\mathrm{CD} 4$ \\
\hline
\end{tabular}

$\square \mathrm{CD} 153+\mathrm{PD}-1+\mathrm{CD} 4$.

C
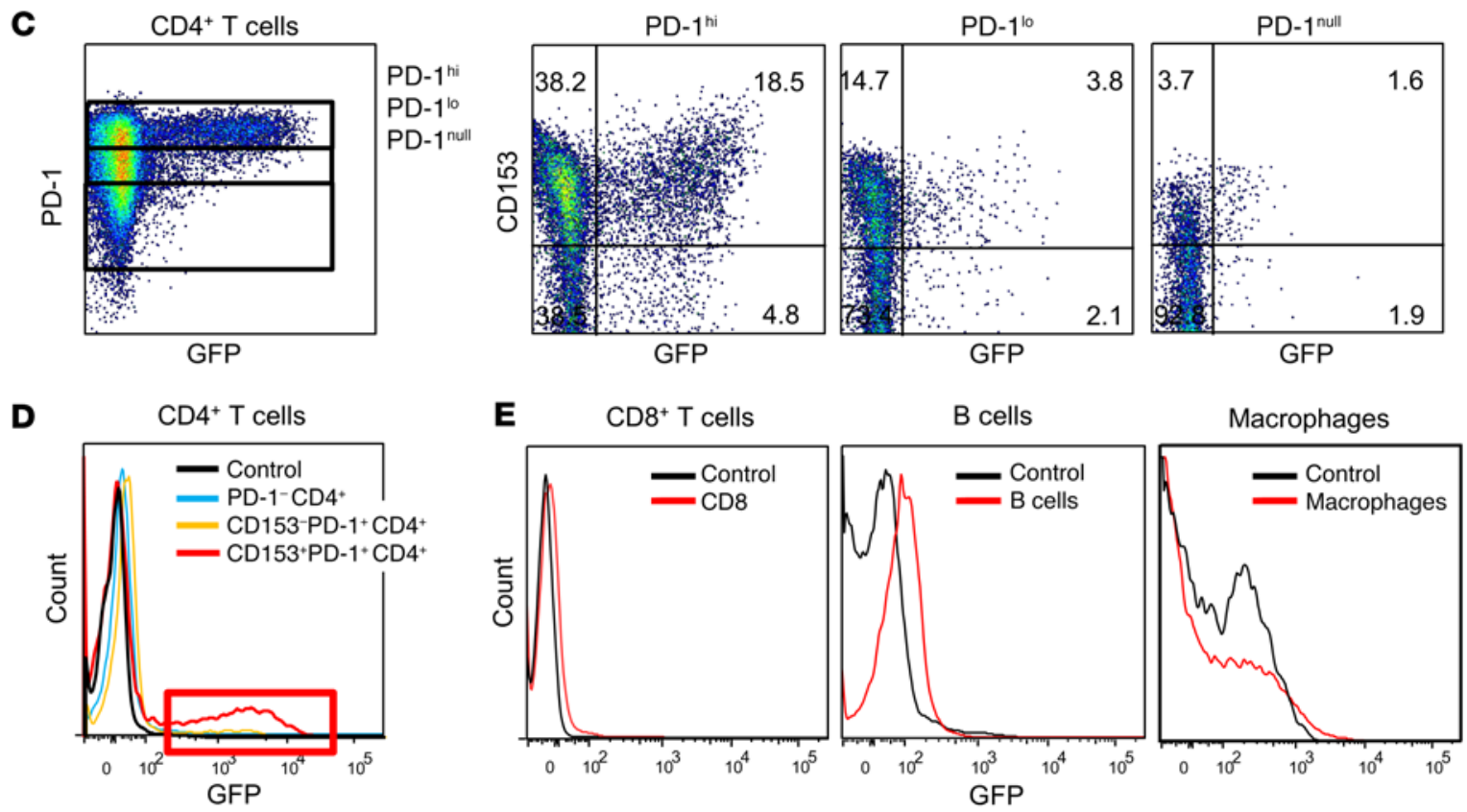

Figure 6. Adipose CD153+PD-1+CD4+ $T$ cells are the main source of OPN in VAT of HFD-fed mice. (A) Representative flow cytometric analysis demonstrat-

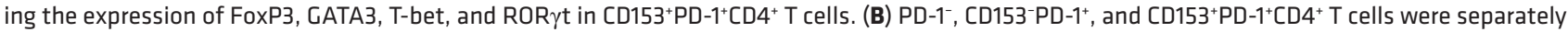
isolated from VAT of WT mice fed an HFD. The indicated CD4 ${ }^{+}$T cells were cultured in the presence of anti-CD3/CD28 mAb for 3 days. IFN- $\gamma$ and OPN concentrations in the culture supernatants were assessed by ELISA ( $n=5$ mice per group). ${ }^{*} P<0.05$ and ${ }^{* * *} P<0.0001$, by ANOVA followed by post hoc Bonferroni tests. (C) Representative flow cytometric analysis of EGFP-Spp1 in PD-1+CD4+ T cells obtained from VAT of EGFP-Spp1-KI reporter mice fed an

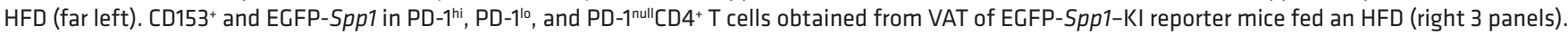

(D) Representative flow cytometric analysis of EGFP-Spp1 in the indicated cells obtained from VAT of EGFP-Spp1-KI reporter mice fed an HFD. Red box shows high fluorescence intensity of GFP in CD153+PD-1+CD4+ $T$ cells. (E) Representative flow cytometric analysis of EGFP-Spp1 in CD8 ${ }^{+} T$ cells, B cells, and macrophages obtained from the VAT of EGFP-Spp1-KI reporter mice fed an HFD. Flow cytometric plots are representative of at least 3 independent experiments. Data represent the mean \pm SEM.

PD- $1^{+} \mathrm{CD} 4^{+} \mathrm{T}$ cells and the $\mathrm{CD} 153^{+}$cell fraction in the PD- $-1^{+} \mathrm{CD} 4^{+}$ $\mathrm{T}$ cells in VAT (Figure 10B). In agreement with these findings and consistent with those of a previous report (16), HFD-fed $\mu$ MT mice showed significantly milder glucose intolerance and insu- lin resistance than did age-matched HFD-fed WT mice (Figure 11A), although the degrees of weight gain and fat deposition were unchanged (Figure 11B). HFD-fed $\mu \mathrm{MT}$ mice also had assuredly reduced expression of Spp1, Ifng, and Tnfa (Figure 11C) as well as 
A

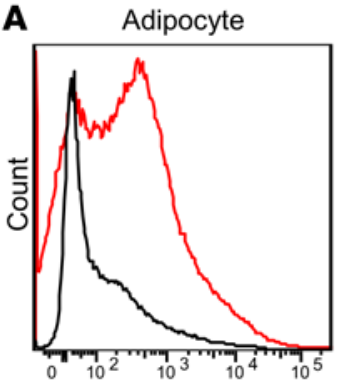

Macrophages

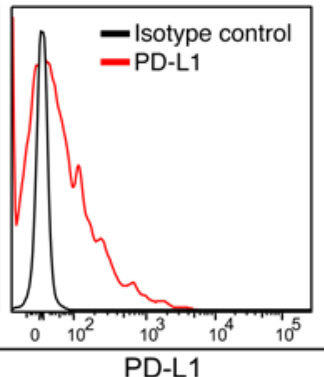

B cells

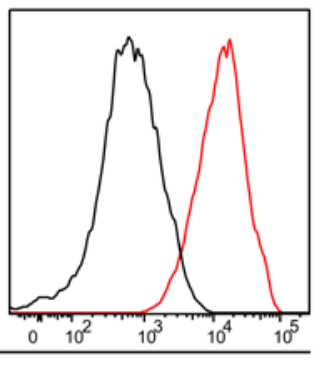

B

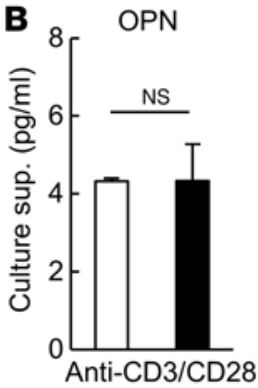

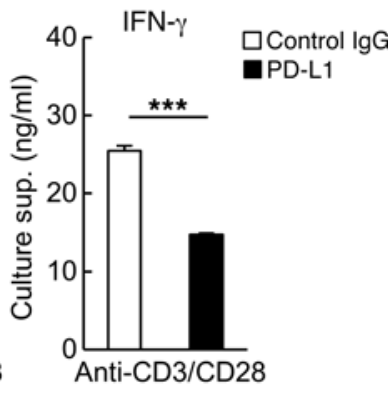

Figure 7. Adipose CD153+PD-1+CD4+ $T$ cells secrete a large amount of OPN independently of the PD-1/PD-L1 inhibitory pathway. (A) Representative flow cytometric analysis of PD-L1 on adipocytes, macrophages, and B cells obtained from VAT of WT mice fed an HFD ( $n=5$ mice per group). (B) CD153 ${ }^{+}$PD- $1^{+}$ $\mathrm{CD}^{+} \mathrm{T}$ cells were cultured in the presence of anti-CD3/28 Abs along with PD-L1-Ig or control reagents for 3 days. IFN- $\gamma$ and OPN concentrations in the culture supernatants were assessed by ELISA ( $n=5$ mice per group). Flow cytometric plots are representative of at least 3 independent experiments. Data represent the mean \pm SEM. ${ }^{* * *} P<0.0001$, by 2-tailed Student's $t$ test.

a compromised increase in $\mathrm{CD} 11 \mathrm{c}^{\text {hi }} \mathrm{CD} 206^{\text {lo }}$ macrophages in VAT compared with HFD-fed WT mice (Figure 11D) and lower levels of OPN in plasma (Figure 11E). These results suggest that B cells play a crucial role in the robust increase of $\mathrm{CD} 153^{+} \mathrm{PD}-1^{+} \mathrm{CD} 44^{\text {hi }} \mathrm{CD} 4^{+}$ $\mathrm{T}$ cells in VAT and, accordingly, in VAT inflammation and metabolic disorder under HFD conditions.

\section{Discussion}

Various types of immune cells have been identified in VAT, and visceral obesity influences the proliferation and function of these immune cells (7-10). In the current study, we found that a unique subset of $\mathrm{CD} 44^{\mathrm{hi}} \mathrm{CD} 44^{+} \mathrm{T}$ cells expressing PD- 1 and CD153 specifically emerged in the VAT of mice fed an HFD. CD $153^{+} \mathrm{PD}-1^{+}$ $\mathrm{CD} 44^{\mathrm{hi}} \mathrm{CD} 4^{+} \mathrm{T}$ cells expressed T-bet with negligible GATA3, ROR $\gamma$, and FoxP3 expression, suggesting a relationship with the Th1 cell lineage. Functionally, however, CD $153^{+} \mathrm{PD}-1^{+} \mathrm{CD} 44^{\mathrm{hi}} \mathrm{CD} 4^{+} \mathrm{T}$ cells preferentially produced large amounts of OPN upon TCR stimulation, while the production of IFN- $\gamma$ and IL-2 was compromised compared with that detected in $\mathrm{PD}-1^{-} \mathrm{CD} 4^{+} \mathrm{T}$ cells. The vast majority of these $\mathrm{T}$ cells also showed a markedly increased expression of SA- $\beta$-gal, $\gamma$-H2AX, and Cdkn1a/Cdkn2b, with reduced Satb1 expression, suggestive of cellular senescence. $S p p 1$ activation in Th1 cells is regulated by T-bet, and deregulated OPN production induces excessive Th1 polarization (46). In addition, T-bet-deficient mice show suppressed proinflammatory immune cell infiltration in VAT and improved glucose homeostasis compared with WT mice (47). It remains to be seen whether the skewed production of large amounts of OPN is due to excessive Th1 polarization or reflects a feature of cellular senescence, namely SA-secretory phenotypes (31). In any case, these T cells were remarkably increased in the VAT of HFD-fed mice, although essentially similar T cells were also detected in much smaller numbers in spleen.

We demonstrated that adoptive transfer of $\mathrm{CD} 153^{+} \mathrm{PD}-1^{+}$ $\mathrm{CD} 44^{\text {hi }} \mathrm{CD} 4^{+} \mathrm{T}$ cells, but not other $\mathrm{CD} 4^{+} \mathrm{T}$ cells, from HFD-fed spleens into VAT of ND-fed mice recapitulates the features of VAT inflammation, including a striking increase in $\mathrm{CD} 11 \mathrm{c}^{\text {hi }} \mathrm{CD} 206^{\text {lo }}$ macrophages and expression of proinflammatory cytokine genes such as Spp1, Ifng, Tnfa, and Il6 in VAT. Importantly, only the recipients of CD153 ${ }^{+} \mathrm{PD}-1^{+} \mathrm{CD} 44^{\mathrm{hi}} \mathrm{CD} 4^{+} \mathrm{T}$ cells developed modest but statistically assured glucose intolerance and increased insulin resistance, strongly suggesting that these unique $\mathrm{CD} 4^{+} \mathrm{T}$ cells play a substantial role in initiating VAT inflammation and metabolic disorder in HFD-fed mice.

OPN has been reported to be increased in the circulating blood of obese diabetic and insulin-resistant patients $(42,48)$ and to play a causative role in VAT inflammation and insulin resistance (19, 49). Using EGFP-Spp1-KI reporter mice, we demonstrated that a significant proportion of CD $153^{+} \mathrm{PD}-1^{+} \mathrm{CD} 44^{\text {hi }} \mathrm{CD} 4 \mathrm{~T}$ cells in situ in VAT of HFD-fed mice showed a remarkable activation of Spp1 in situ that was far greater than that found in macrophages. Adoptive transfer of CD $153^{+} \mathrm{PD}-1^{+} \mathrm{CD} 44^{\mathrm{hi}} \mathrm{CD} 4^{+} \mathrm{T}$ cells from $\mathrm{HFD}$-fed $\mathrm{Spp1^{-/ }}$ mice failed to induce VAT inflammation or insulin resistance, indicating a crucial role of the OPN produced by these T cells in VAT.

Nishimura et al. focused on the regulatory B cell (Breg) subset and reported that the proportion and function of Bregs were reduced in HFD-fed VAT, suggesting that Breg dysfunction contributes to the progression of VAT inflammation in obesity (50). OPN activates B cells to produce Igs, while it suppresses IL-10 production by B cells (51). The current study suggests that OPN secreted by $\mathrm{CD} 153^{+} \mathrm{PD}-1^{+} \mathrm{CD} 44^{\text {hi }} \mathrm{CD} 4 \mathrm{~T}$ cells contributes to the Breg dysfunction we observed in HFD-fed VAT.

In our study, the HFD-fed $\mu \mathrm{MT}$ mice had markedly decreased numbers of $\mathrm{CD} 153^{+} \mathrm{PD}-1^{+} \mathrm{CD} 44^{\mathrm{hi}} \mathrm{CD} 4^{+} \mathrm{T}$ cells in VAT, suggesting that $\mathrm{B}$ cells were required for their optimal increase. We previously reported that $\mathrm{CD} 153^{+} \mathrm{PD}-1^{+} \mathrm{CD} 44^{\mathrm{hi}} \mathrm{CD} 4^{+} \mathrm{T}$ cells in splenic $\mathrm{GC}$ cells of lupus-prone mice are activated to produce OPN in response to GC B cells in a TCR/MHC class II-dependent manner (31), and we currently report that obese VAT contains $\mathrm{GL}-7^{+}$GC-like B cells. Thus, an intriguing possibility may be that B cells function as antigen-presenting cells to drive the generation of CD $153^{+} \mathrm{PD}-1^{+}$ $\mathrm{CD} 44^{\text {hi }} \mathrm{CD}^{+} \mathrm{T}$ cells in VAT, although the nature of the antigens remains to be elucidated. The B cells and macrophages in VAT were found to strongly express PD-L1 (35-38), a ligand for the negative PD-1 receptor. Notably, however, our study showed that TCR-induced OPN production by $\mathrm{CD} 153^{+} \mathrm{PD}-1^{+} \mathrm{CD} 44^{\mathrm{hi}} \mathrm{CD} 4^{+} \mathrm{T}$ cells was hardly affected by PD-1 signaling, suggesting that the activation of these T cells in VAT is not under checkpoint control and allows the chronic progression of VAT inflammation.

Although our study focused on a unique $\mathrm{CD} 4^{+} \mathrm{T}$ cell subpopulation in VAT of HFD-fed obese mice, we found that the numbers 

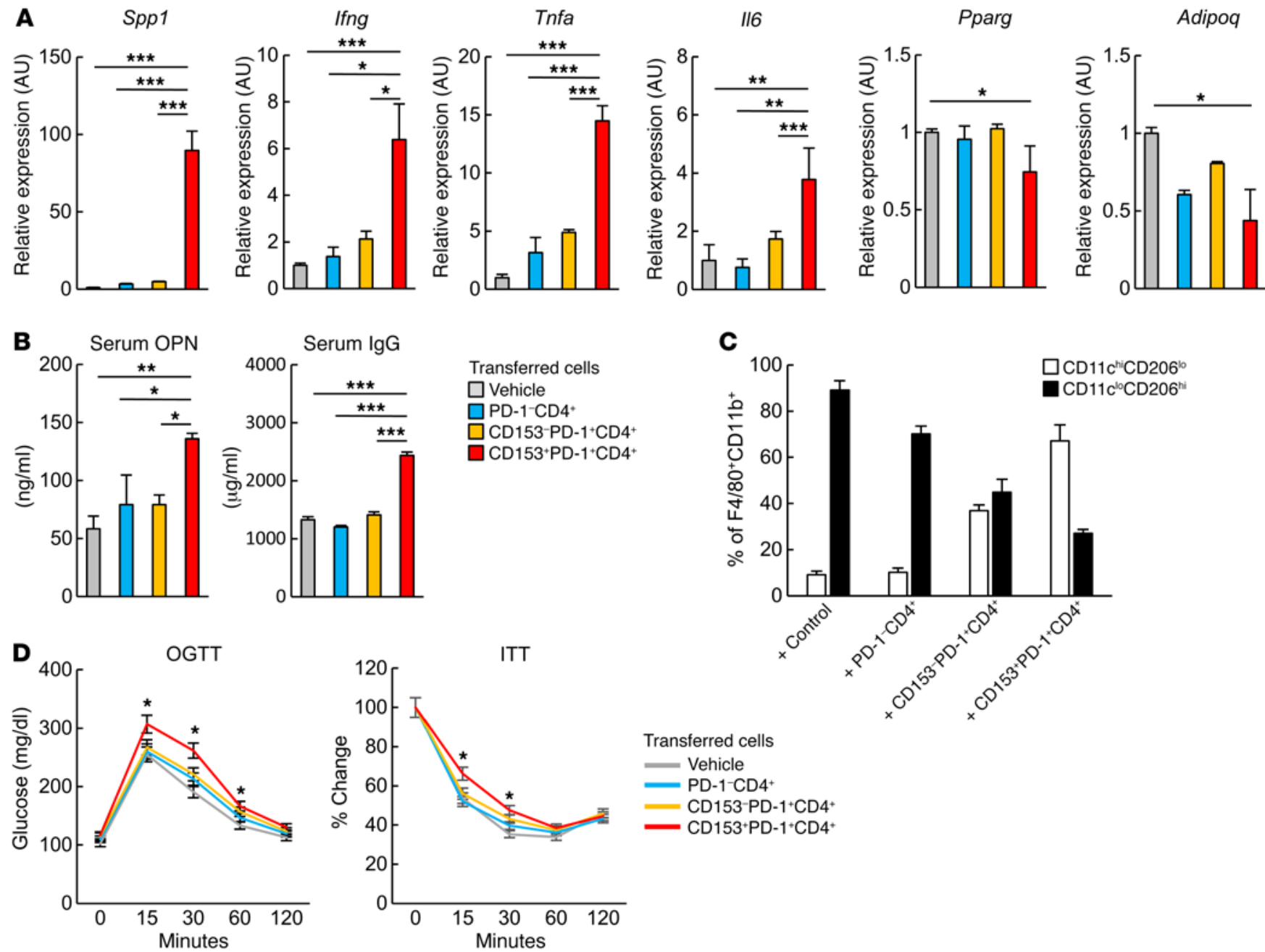

$\square \mathrm{CD} 153+\mathrm{PD}-1+\mathrm{CD} 4$

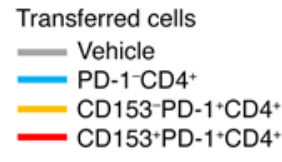

Figure 8. Adoptive transfer of CD153+PD-1+CD4+ ${ }^{+}$cells induces VAT inflammation and insulin resistance in lean mice on an ND. $^{+}$(A-D) PD-1 ${ }^{-}$, CD153-PD-1+ and CD153+PD-1+CD4+ T cells were separately isolated from the spleens of WT mice fed an HFD. Next, $1 \times 10^{5}$ cells were transferred directly into VAT of individual recipient ND-fed lean mice 3 times per week for 2 weeks, starting at 18 weeks of age. ND-fed lean mice receiving vehicle (thermoreversible gelation polymer) were used as the control group. (A) Real-time PCR analyses of Spp1, Ifng, Tnfa, II6, and Adipoq, Parg expression levels in VAT of recipient mice ( $n=5$ mice per group). (B) Analyses of serum OPN and IgG concentrations in recipient mice ( $n=5$ mice per group). (C) Analyses of CD11c ${ }^{\text {hicD206 }}{ }^{\text {lo }}$ macrophage and $\mathrm{CD} 11 \mathrm{C}^{\mathrm{lo}} \mathrm{CD} 206^{\mathrm{hi}}$ macrophage ratios in the VAT of recipient mice ( $n=5$ mice per group). (D) Effects of adoptive transfer of control reagents or $\mathrm{PD}-1^{-}, \mathrm{CD} 153^{-} \mathrm{PD}-1^{+}$, or $\mathrm{CD} 153^{+} \mathrm{PD}-1^{+} \mathrm{CD} 4^{+} \mathrm{T}$ cells on the oral glucose tolerance test (OGTT) (C) and insulin tolerance test (ITT) (D) ( $n=5$ mice per group). ${ }^{*} P<0.05$, for $\mathrm{CD} 153^{+} \mathrm{PD}-1^{+} \mathrm{CD} 4^{+} \mathrm{T}$ cells versus vehicle alone. Data represent the mean $\pm \mathrm{SEM}$. ${ }^{*} P<0.05$, ${ }^{*} P<0.001$, and ${ }^{*}{ }^{*} P<0.0001$, by ANOVA followed by post hoc Bonferroni tests

of $\mathrm{CD} 8^{+}$cells were also significantly increased in VAT of ND-fed mice, with a marked B cell-dependent predominance of CD44 $4^{\mathrm{hi}}$ CD62L ${ }^{\text {lo }}$ cells. However, these $\mathrm{CD} 8^{+} \mathrm{T}$ cells expressed very little CD153, nor did they show activation of the Spp1 gene. Thus, we hypothesize that $\mathrm{CD} 8^{+} \mathrm{T}$ cells show different features and behave in different ways from $\mathrm{CD} 4^{+} \mathrm{T}$ cells in HFD-fed VAT. Their exact features remain to be investigated and will be the subject of future research by our group.

It is noteworthy that $\mathrm{CD} 153^{+} \mathrm{PD}-1^{+} \mathrm{CD} 4^{+} \mathrm{T}$ cells in VAT of HFD-fed mice show features indistinguishable from those of $\mathrm{CD}^{153^{+}} \mathrm{SA}-\mathrm{T}$ cells, which gradually increase systemically with age (31). The age-dependent increase in $\mathrm{CD} 153^{+} \mathrm{SA}-\mathrm{T}$ cells may partly underlie the immune aging, including a reduction in acquired immunity and an increase in the inflammatory trait and autoimmunity risk $(26,52)$. Obesity is also associated with diminished resistance against infection (8), chronic low-grade inflammation $(53,54)$, and a greater susceptibility to autoimmunity $(55)$. It has been suggested that the increase in $\mathrm{CD}_{153^{+}} \mathrm{SA}^{-} \mathrm{T}$ cells in chronological aging and systemic autoimmunity is attributable to a robust, homeostatic $\mathrm{T}$ cell proliferation (31), but the precise mechanism underlying the accumulation of these T cells in VAT of HFD-fed mice remains to be investigated. Nonetheless, it is an intriguing possibility that the predisposition often associated with obesity may partly be a systemic manifestation of the premature increase in $\mathrm{CD}_{153^{+}} \mathrm{SA}-\mathrm{T}$ cells in VAT, since adipose tissues can constitute up to $50 \%$ to $60 \%$ of total BW in severe obesity (7).

In conclusion, we have demonstrated that a unique subpopulation of $\mathrm{CD} 4^{+} \mathrm{T}$ cells expressing $\mathrm{PD}-1$ and $\mathrm{CD} 153$ plays an important role in VAT inflammation and insulin resistance under HFD conditions through OPN production. The current results under- 

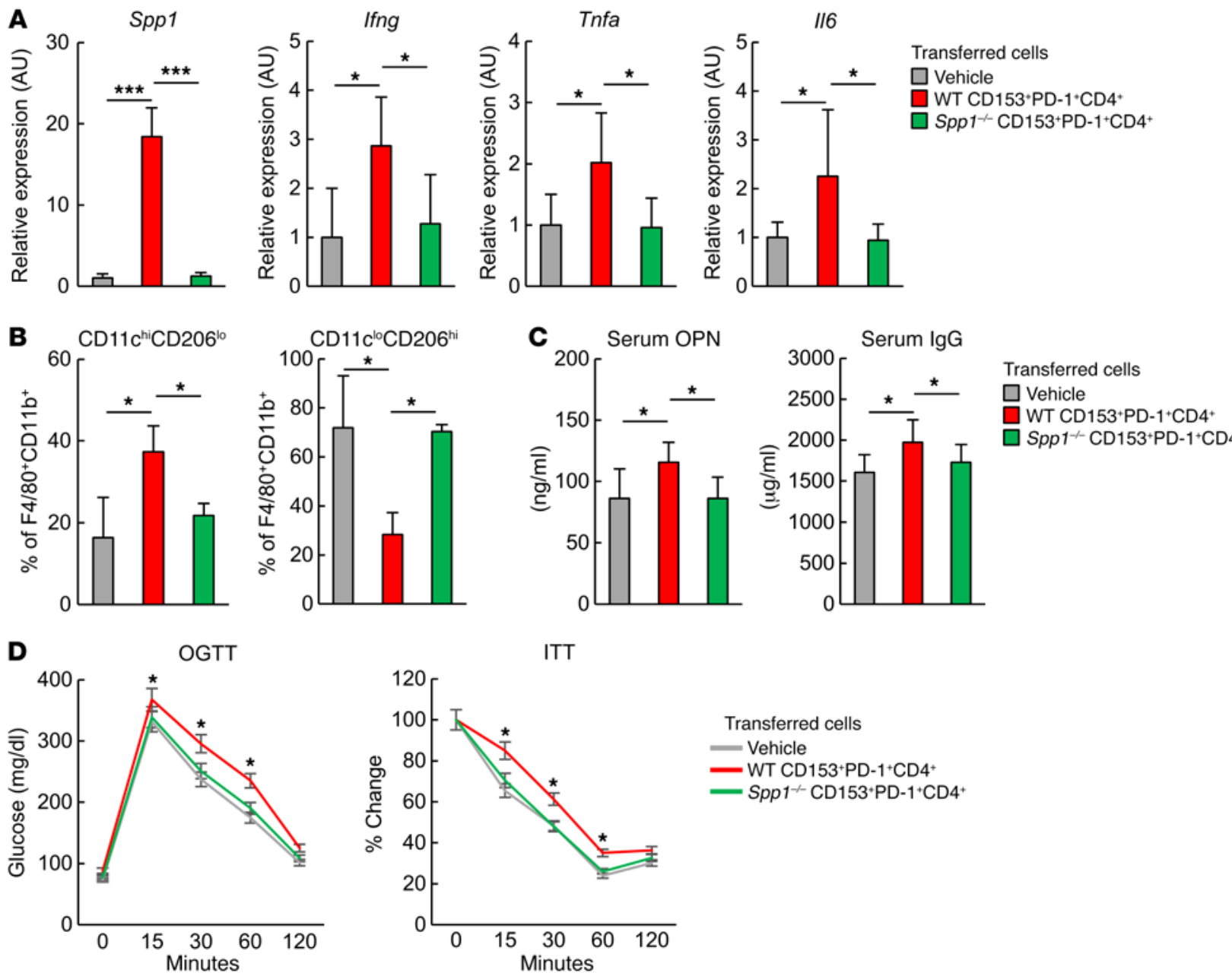

Figure 9. CD153+PD-1+CD4+ T cells cause VAT inflammation and insulin resistance by secreting OPN. (A-D) Splenic CD153+PD- $1^{+} C D 4^{+} T$ cells were separately isolated from HFD-fed WT and Spp1/-- mice, respectively. Cells $\left(1 \times 10^{5}\right)$ were transferred directly into VAT of individual recipient ND-fed lean mice 3 times per week for 2 weeks, starting at 18 weeks of age. ND-fed lean mice receiving vehicle (thermoreversible gelation polymer) were used as the control group. (A) Analyses of Spp1, Ifng, Tnfa, and I/6 expression by real-time PCR in VAT of recipient mice ( $n=5$ mice per group). (B) Analyses of CD11 ${ }^{\text {hiCD206 }}$ lo macrophages and $\mathrm{CD} 11 \mathrm{C}^{\mathrm{lo}} \mathrm{CD} 206^{\mathrm{hi}}$ macrophage ratios in VAT of recipient mice ( $n=5$ mice per group). (C) Analyses of serum OPN and IgC concentrations in recipient mice ( $n=6$ mice per group). (D) Effects of adoptive transfer of control reagent or CD153+PD-1+CD4+ $T$ cells from WT or Spp1 ${ }^{1--}$ mice fed an HFD as determined by OGTT and ITT ( $n=10$ mice per group). ${ }^{*} P<0.05$, for WT CD153 ${ }^{+} \mathrm{PD}-1^{+} \mathrm{CD} 4^{+}$T cells versus vehicle $(n=10$ mice per group). Data represent the mean \pm SEM. ${ }^{*} P<0.05$ and ${ }^{* *} P<0.0001$, by ANOVA followed by post hoc Bonferroni tests

score a possible link between visceral obesity and immune aging and may provide a cellular target for controlling immunometabolic anomalies in visceral obesity.

\section{Methods}

Animal work. C57BL/6 (B6) mice were purchased from Japan SLC Inc., and $\mu \mathrm{MT}$, Spp1-KO, and EGFP-Spp1-KI reporter mice were described before (31). All mice were housed under a 12-hour light/12-hour dark cycle and allowed free access to food. Mice were fed with either a ND (CE-2, $6 \mathrm{kcal} \%$ fat; CLEA Japan Inc.) or an HFD (D12492, $60 \mathrm{kcal \%}$ fat; Research Diets Inc.). We used littermate controls in the experiments involving Spp1-KO and EGFP-Spp1-KI reporter mice on a B6 background. B6 mice were used as a control for $\mu \mathrm{MT}$ mice (which were purchased from The Jackson Laboratory), according to The Jackson Laboratory's recommendation.

Isolation of the stromal vascular fraction and flow cytometry. We isolated stromal vascular cells using previously described methods, with some modifications. Mice were sacrificed under general anesthesia after systemic heparinization. VAT was removed and ground into small pieces. Samples were incubated for 40 minutes in collagenase II/DNase I solution ( $1 \mathrm{mg} / \mathrm{ml}$ collagenase II and $50 \mu \mathrm{g} / \mathrm{ml}$ in HBSS solution), with gentle stirring. Digested tissue was then centrifuged at $1,000 \mathrm{~g}$ for 10 minutes. The resulting pellets were washed twice with cold PBS and filtered through a 70-mm mesh. Red blood cells were lysed with erythrocyte-lysing buffer (eBioscience) for 5 minutes and resuspended in RPMI-1640 supplemented with 10\% FBS. Single-cell suspensions of splenocytes and the adipose stromal vascular fraction (SVF) were blocked with CD16/32 mAb (2.4G2; BD Biosciences) at $4^{\circ} \mathrm{C}$ for 5 minutes. Cells were stained with a mixture of Abs at $4^{\circ} \mathrm{C}$ for 20 minutes. Flow cytometric analysis and cell sorting were performed on a FACSAria III instrument (BD Biosciences) and analyzed using FlowJo software. The purity of the sorted cells was consistently more than $95 \%$ by post-sorting analysis. The representative post-sorting analyses are shown in Supplemental Figure 7. 
A

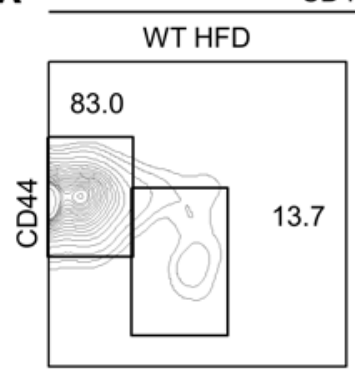

CD62L

B

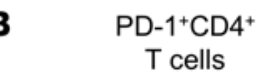

$\mathrm{CD}^{+} \mathrm{T}$ cells

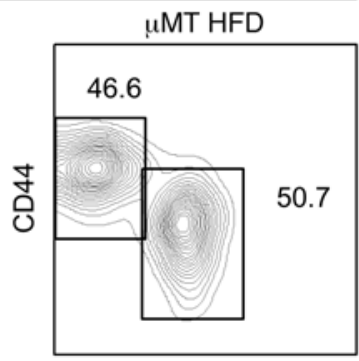

CD62L
$\mathrm{CD} 44^{10} \mathrm{CD} 62 \mathrm{~L}^{\mathrm{h}}$

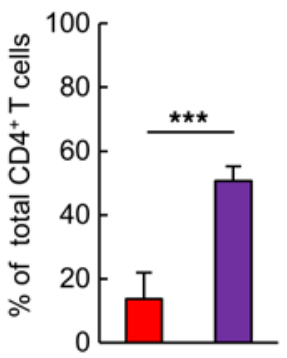

CD44 ${ }^{\text {hi }}$ CD62 $L^{\text {lo }}$

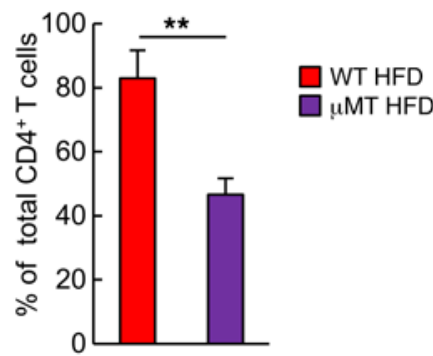

$\mathrm{CD}_{153}{ }^{+} \mathrm{PD} 1^{+}$ $T$ cells
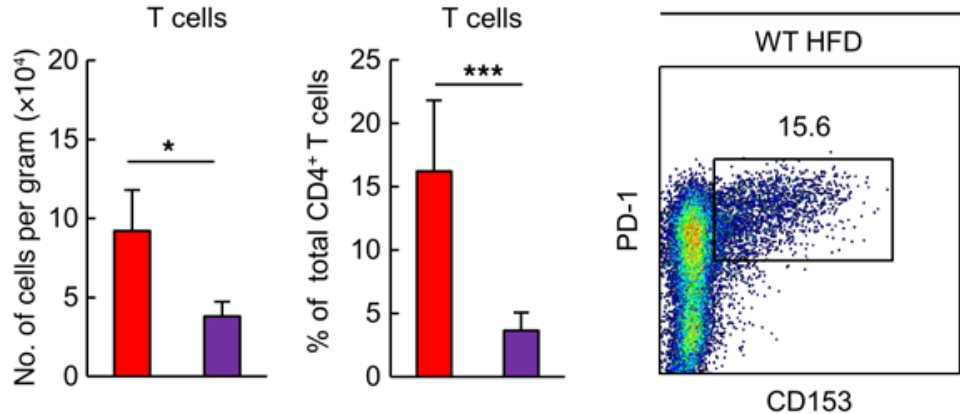

$\mathrm{CD}^{+} \mathrm{T}$ cells

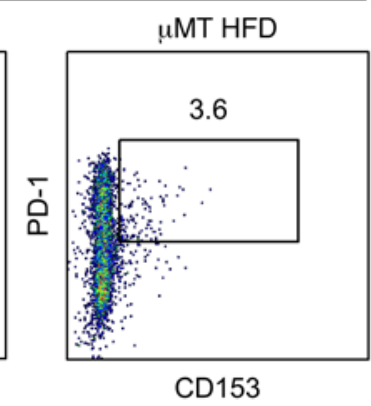

Figure 10. Adipose B cells are essential for the HFD-induced emergence of CD153+PD-1+CD4+ $\mathbf{T}$ cells. WT and $\mu$ MT mice were examined after 14 weeks on an ND or HFD. (A) Analyses of VAT CD44 ${ }^{10} \mathrm{CD} 62 \mathrm{~L}^{\text {hi }}$ and VAT CD44 hi CD62 $\mathrm{L}^{10}$ cells ( $n=6$ mice per group). (B) Analyses of VAT PD- $1^{+} \mathrm{CD} 4^{+} \mathrm{T}_{\text {cells }}$ and CD153 $3^{+} \mathrm{PD}-1^{+}$ $\mathrm{CD}^{+} \mathrm{T}$ cells ( $n=6$ mice per group). Data represent the mean $\pm \mathrm{SEM} .{ }^{*} P<0.05,{ }^{*} P<0.001$, and ${ }^{* * *} P<0.0001$, by 2 -tailed Student's $t$ test.

The Abs used were specific to CD3 (14A-2; BioLegend); CD4 (GK1.5; BioLegend); CD8a (53-6.7 and OKT8; eBioscience); CD44 (IM7; BioLegend); CD62L (MEL-14; eBioscience); CD11b (M1/70; eBioscience); F4/80 (BM8; BioLegend); CD11c (N418; eBioscience); CD206 (MR5D3; Biolegend); PD-1 (RMP1-30 and 29F.1A12; BioLegend); CD45 (30F11.1; eBioscience); CD19 (1D3; eBioscience); PD-L1 (10F.9G2; BioLegend); CD153 (RM153; BioLegend); GL7 (GL7; BioLegend); and 7-AAD viability staining solution (BioLegend). We analyzed intracellular cytokine production with a Cytofix/Cytoperm Fixation/Permeabilization Solution Kit (BD Pharmingen) and a transcriptional factor using a True-Nuclear Transcription Factor Buffer Set (BioLegend). The Abs used were specific to FoxP3 (FJK-16s; eBioscience); T-bet (4B10; BioLegend); GATA3 (16E10A23; BioLegend); ROR $\gamma \mathrm{t}$ (B2D; eBioscience); and $\gamma$-H2AX (N1-431; BD Pharmingen).

IHC. Whole-mount VAT was stained and visualized. Mice were sacrificed by cervical dislocation, after which VAT was removed using sterile technique and minced into small pieces $(\sim 2-3 \mathrm{~mm})$ using a scalpel. Tissue pieces were washed, fixed in cellFIX (catalog 340181; $\mathrm{BD}$ ) for 60 minutes, and permeabilized with $0.1 \%$ Triton $\mathrm{X}-100$ for 10 minutes. The specimens were then blocked with 5\% BSA and incubated with primary Abs specific to CD3 (145-2C11; BD); PD-1 (J43; Bio X Cell); F4/80 (BM-8; eBioscience); and CD153 (RM153; eBioscience) for 1 hour and then with Alexa Fluor 488- and 647-conjugated secondary Abs (Molecular Probes, Thermo Fisher Scientific) for 1 hour. The tissues were counterstained for 1 hour with BODIPY 558/568 (Molecular Probes, Thermo Fisher Scientific) to visualize adipocytes and with DAPI (Molecular Probes, Thermo Fisher Scientific) to visualize nuclei. The vasculature was stained with Griffonia simplicifolia B4 isolectin conjugated with Alexa Fluor 488 (FL-1201; Vector Labo- ratories) for 1 hour. Tissue samples were excited using 4 wavelengths $(405,488,568$, and $800 \mathrm{~nm})$ and the emission collected through the appropriate narrow band-pass filters on a confocal microscope (LSM 510 META; Carl Zeiss). The images were acquired and processed using LSM 510 software (Carl Zeiss).

Quantitative real-time PCR. Total RNA samples from sorted cells and VAT were prepared using an RNeasy Mini Kit (QIAGEN) or TRIzol reagent (Invitrogen, Thermo Fisher Scientific) according to the manufacturers' instructions. A First-Strand cDNA Synthesis Kit (Invitrogen, Thermo Fisher Scientific) was used for cDNA synthesis. Quantitative real-time PCR was performed using the ABI PRISM 7700 Sequence Detection System (Applied Biosystems) or the ViiA 7 Real-Time PCR System (Thermo Fisher Scientific). The Gapdh gene was used as an endogenous control to normalize for differences in the amount of total RNA in each sample. All values were expressed as a fold increase or decrease relative to the expression of Gapdh. The primer sequences for genes were as follows: Gapdh, 5'-AGGTCGGTGTGAACGGATTTG and 3'-TGTAGACCATGTAGTTGAGGTCA; Spp1, 5'-CCCGGTGAAGTGCTGATT and 3'-TTCTTCAGAGGACACAGCATTC; Ifng, 5'-ATCTGGAGGAACTGGCAAAA and 3'-TTCAAGACTTCAAAGAGTCTGAGG; Cebpa, 5'-TGAgAAAAATGAAGGGTGCAG and 3'-CGGGATCTCAGCTTCCTGT; Satb1, 5'-ACTGAAACGAGCCGGAATC and 3'-CGGAGGATTTCAGAAAGCAA; Tnfa, 5'-CCCTCACACTCAGATCATCTTCT and 3'-GCTACGACGTGGGCTACAG; Eefla1, 5'-CAACATCGTCGTAATCGGACA and 3'-GTCTAAGACCCAGGCGTACTT; Dusp10， 5'-CCATCTCCTTTAGACGACAGGG and 3'-GCTACCACTACCTGGGCTG; Emr1, 5'-TTGTACGTGCAACTCAGGACT and 3'-GATCCCAGAGTGTTGATGCAA; Pparg, 5'-TCGCTGATGCACTGCCTATG and 3'-GAGAGGTC- 

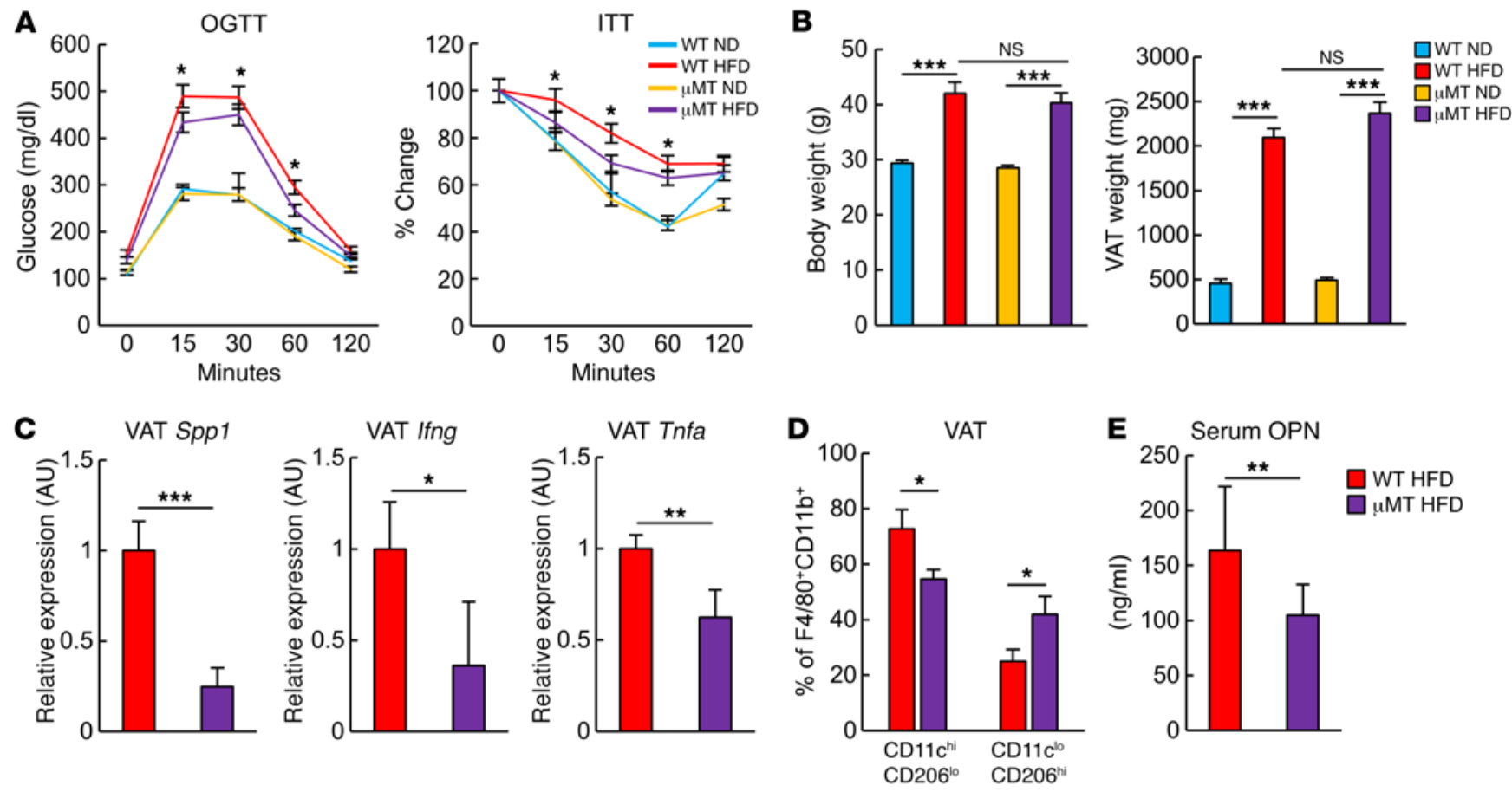

Figure 11. B cell deficiency ameliorates VAT inflammation and insulin resistance in obesity. WT and $\mu$ MT mice were examined after 14 weeks on an ND or HFD. (A) OGTT and ITT results ( $n=5$ mice per group). ${ }^{*} P<0.05$, for WT HFD-fed mice versus $\mu$ MT HFD-fed mice, by ANOVA followed by post hoc Bonferroni tests. (B) BW and VAT weight ( $n=5$ mice per group). (C) Analyses of Spp1, Ifng, and Tnfa expression in VAT by real-time PCR analysis ( $n=5$ mice per group). (D) Comparison of CD11 $c^{\text {hi }} C D 206^{10} / C D 11 c^{10} C D 206^{\text {hi }}$ macrophage ratios between WT and $\mu$ MT mice fed an HFD ( $n=6$ mice per group). (E) Comparison of serum OPN concentrations between WT and $\mu$ MT mice fed an HFD ( $n=6$ mice per group). Data represent the mean \pm SEM. ${ }^{*} P<0.05,{ }^{* *} P<0.001$, and ${ }^{* *} P<0.0001$, by 2 -tailed Student's t test.

CACAGAGCTGATT; Adipoq, 5'-TGTTCCTCTTAATCCTGCCCA and 3'-CCAACCTGCACAAGTTCCCTT; Tgfb1, 5'-CTCCCGTGGCTTCTAGTGC and 3 '-GCCTTAGTTTGGACAGGATCTG; Cdkn1a, 5'-AACATCTCAGGGCCGAAA-3' and 5'-TGCGCTTGGAGTGATAGAAA- $3^{\prime}$; and $C d k n 2 b, 5^{\prime}$-AATAACTTCCTACGCATTTTCTGC- ${ }^{\prime}$ and $5^{\prime}$-CCCTTGGCTTCAAGGTGAG-3'.

Glucose and insulin tolerance tests. We performed glucose tolerance (oral administration of $1.5 \mathrm{~g} / \mathrm{kg}$ of glucose, after 16 hours of fasting) and insulin tolerance (administration of $0.75 \mathrm{U} / \mathrm{kg}$ of insulin i.p. after 4 hours of fasting) tests to assess glucose intolerance and insulin resistance.

$B$ cell helper assay. B cells $\left(3 \times 10^{5}\right)$ from VAT and spleen were purified by positive selection using anti-CD19 MACS Beads (Miltenyi Biotec) according to the manufacturer's instructions; the B cells were generally more than $95 \% \mathrm{CD} 19^{+} \mathrm{B} 220^{+}$. For coculture experiments, $\mathrm{PD}-1^{-} \mathrm{CD} 4^{+}$, CD $153^{-} \mathrm{PD}-1^{+}$, and $\mathrm{CD} 153^{+} \mathrm{PD}-1^{+} \mathrm{CD} 4^{+} \mathrm{T}$ cells were sorted from VAT or spleens of WT mice fed an HFD. These were stimulated with $5 \mu \mathrm{g} / \mathrm{ml}$ plate-bound anti-CD3 with anti-OPN Ab ( $2 \mu \mathrm{g} / \mathrm{ml}$; Sigma-Aldrich) or control IgG and mixed with B cells at a 1:3 T cell/B cell ratio in U-bottomed 96-well plates. We used 5-7 mice per sample of the indicated cells (Supplemental Figure 5D). Ten days later, the total IgG concentration of the supernatants was determined by ELISA (eBioscience).

$T$ cell culture. $\mathrm{CD}^{+} \mathrm{T}$ cells or $\mathrm{CD}^{+} \mathrm{T}$ cells $\left(1 \times 10^{5}\right)$ were stimulated with immobilized anti-CD3 $\mathrm{mAb}(5 \mu \mathrm{g} / \mathrm{ml})$ with soluble antiCD28 mAb $(2.5 \mu \mathrm{g} / \mathrm{ml})$ in the presence or absence of $1 \mu \mathrm{g} / \mathrm{ml}$ mouse recombinant OPN for 72 hours. We used 5-7 mice per sample of the cells. PD-L1-Ig or control IgG (R\&D Systems) was additionally included in the culture.
B cell culture. VAT B cells $\left(1 \times 10^{5}\right)$ were purified by positive selection using anti-CD19 MACS Beads (Miltenyi Biotec) according to the manufacturer's instructions and were generally more than $95 \%$ $\mathrm{CD}_{19}{ }^{+} \mathrm{B} 22 \mathrm{O}^{+}$. B cells were cultured in DMEM supplemented with $10 \%$ FBS plus LPS from Escherichia coli $(1 \mu \mathrm{g} / \mathrm{ml}$; Sigma-Aldrich) in the presence or absence of recombinant OPN for 72 hours. We used 3 mice per sample of the cells.

ELISA. The levels of OPN (R\&D Systems); IFN- $\gamma$ (BioLegend); IL-17 (R\&D Systems); and total IgG (eBioscience) in supernatants or serum were determined by ELISA according to the manufacturers' instructions.

Migration of peritoneal macrophages. We isolated $1 \times 10^{5} \mathrm{PD}-1^{-}$, CD153-PD- $1^{+}$, and CD153 ${ }^{+} \mathrm{PD}-1^{+} \mathrm{CD} 4^{+} \mathrm{T}$ cells from VAT of HFD-FED WT mice. We used 5-7 mice per sample of the cells. These cells were cultured in complete RPMI with immobilized anti-CD3 mAb (5 $\mu \mathrm{g} /$ $\mathrm{ml})$ and soluble anti-CD28 mAb $(2.5 \mu \mathrm{g} / \mathrm{ml})$. After 120 hours of culture, the culture medium was aspirated and analyzed by a migration assay using Boyden chambers with 8-mm pore inserts (BD). Peritoneal macrophages were cultured in the upper wells, and the conditioned medium was added to the lower wells. We used fresh DMEM supplemented with 5\% FBS as a control. To inhibit OPN activity, an anti-OPN Ab ( $2 \mu \mathrm{g} / \mathrm{ml}$; Sigma-Aldrich) or control IgG was added to the conditioned medium.

Adoptive transfer of $T$ cells into recipient mice. $\mathrm{PD}-1^{-}, \mathrm{CD} 153^{-} \mathrm{PD}-1^{+}$, and $\mathrm{CD} 153^{+} \mathrm{PD}-1^{+} \mathrm{CD} 4^{+} \mathrm{T}$ cells were sorted from the spleens of HDFfed WT mice (Figure 5), and CD $153^{+} \mathrm{PD}-1^{+} \mathrm{CD} 4^{+} \mathrm{T}$ cells were sorted from the spleens of WT or $S p p 1^{-/-}$mice fed an HFD (Figure 6). Sorted $\mathrm{CD}^{+} \mathrm{T}$ cells were mixed with a thermoreversible gelation polymer 
(Mebiol Gel; Cosmo Bio). We transferred $1 \times 10^{5}$ cells into VAT of recipient mice fed an ND directly under echographic guidance, 3 times per week for 2 weeks, starting at the indicated age (Figure 8 and 9). The vehicle (thermoreversible gelation polymer) was similarly injected into the control mice.

Cellular senescence assay. We isolated the SVF from VAT and splenocytes of HFD-fed WT mice. SA- $\beta$-gal assays were performed using a Cellular Senescence Live Cell Analysis Kit (Enzo Life Sciences).

Statistics. All values are presented as the mean \pm SEM. The statistical significance of differences between 2 groups was determined using a 2-tailed Student's $t$ test. Differences among multiple groups were compared using ANOVA followed by Bonferroni's post-hoc tests. A $P$ value of less than 0.05 was considered significant.

Study approval. This study conformed to NIH guidelines (Guide for the Care and Use of Laboratory Animals. National Academies Press. 1996.) and was approved by the IACUC of the Keio University School of Medicine.

\section{Author contributions}

K. Shirakawa conducted most of the experiments. XY obtained the preliminary results. K. Shinmura, JE, MK, YK, TY, AA, NY, and M. Sekai and SI helped with the experimental work. HI, IM, YH, and
KF supervised the study. M. Sano and K. Shinmura designed the experiments. NM and M. Sano wrote the manuscript.

\section{Acknowledgments}

We thank K. Tamaki, Y. Miyake, S. Matsumoto, and H. Yagita for their technical assistance. This study was supported in part by a grant from the Japan Society for the Promotion of Science KAKENHI (22590814; 2013-2015); the Japan Foundation for Aging and Health (2013-2014); the Takeda Medical Research Foundation (2013-2014); the $3^{\text {rd }}$ Annual Research Award Grant of Japanese Anti-Aging Medicine (2011; to Dr. Shinmura); the Vehicle Racing Commemorative Foundation (2012-2014; to Dr. Shinmura and Dr. Sano); the JST PREST (2013-2015); and the JSPS KAKENHI (2015-2016; 15H04825 and 15H01160, to Dr. Sano).

Address correspondence to: Motoaki Sano, Department of Cardiology, Keio University School of Medicine, 35 Shinanomachi, Shinjuku-ku, Tokyo 160-8582, Japan. Phone: 81.3.5363.3874; E-mail: msano@a8.keio.jp. Or to: Nagahiro Minato, Department of Immunology and Cell Biology, Graduate School of Medicine, Kyoto University, Kyoto 606-8501, Japan. Phone: 81.75.753.4659; E-mail: minato@imm.med.kyoto-u.ac.jp.
1. Adams KF, et al. Overweight, obesity, and mortality in a large prospective cohort of persons 50 to 71 years old. N Engl J Med. 2006;355(8):763-778.

2. Bosello O, Zamboni M. Visceral obesity and metabolic syndrome. Obes Rev. 2000;1(1):47-56.

3. Chiba Y, et al. Relationship between visceral fat and cardiovascular disease risk factors: the Tanno and Sobetsu study. Hypertens Res. 2007;30(3):229-236.

4. Després JP. Is visceral obesity the cause of the metabolic syndrome? Ann Med. 2006;38(1):52-63.

5. Després JP. Body fat distribution and risk of cardiovascular disease: an update. Circulation. 2012;126(10):1301-1313.

6. Katzmarzyk PT, Janssen I, Ardern CI. Physical inactivity, excess adiposity and premature mortality. Obes Rev. 2003;4(4):257-290.

7. Grant RW, Dixit VD. Adipose tissue as an immunological organ. Obesity (Silver Spring). 2015;23(3):512-518.

8. Kanneganti TD, Dixit VD. Immunological complications of obesity. Nat Immunol. 2012;13(8):707-712.

9. DiSpirito JR, Mathis D. Immunological contributions to adipose tissue homeostasis. Semin Immunol. 2015;27(5):315-321.

10. Mathis D. Immunological goings-on in visceral adipose tissue. Cell Metab. 2013;17(6):851-859.

11. Cho KW, et al. An MHC II-dependent activation loop between adipose tissue macrophages and CD4+ T cells controls obesity-induced inflammation. Cell Rep. 2014;9(2):605-617.

12. Finlay D, Cantrell DA. Metabolism, migration and memory in cytotoxic T cells. Nat Rev Immunol. 2011;11(2):109-117.

13. Strissel KJ, DeFuria J, Shaul ME, Bennett G, Greenberg AS, Obin MS. T-cell recruitment and Th1 polarization in adipose tissue during dietinduced obesity in C57BL/6 mice. Obesity (Silver Spring). 2010;18(10):1918-1925.
14. Yang $\mathrm{H}$, et al. Obesity increases the production of proinflammatory mediators from adipose tissue $\mathrm{T}$ cells and compromises TCR repertoire diversity: implications for systemic inflammation and insulin resistance. J Immunol. 2010;185(3):1836-1845.

15. Morris DL, et al. Adipose tissue macrophages function as antigen-presenting cells and regulate adipose tissue $\mathrm{CD} 4^{+} \mathrm{T}$ cells in mice. Diabetes. 2013;62(8):2762-2772.

16. Winer DA, et al. B cells promote insulin resistance through modulation of T cells and production of pathogenic IgG antibodies. Nat Med. 2011;17(5):610-617.

17. Nishimura S, et al. CD8+ effector T cells contribute to macrophage recruitment and adipose tissue inflammation in obesity. Nat Med. 2009;15(8):914-920.

18. Trifari S, Kaplan CD, Tran EH, Crellin NK, Spits $H$. Identification of a human helper $\mathrm{T}$ cell population that has abundant production of interleukin 22 and is distinct from $\mathrm{T}(\mathrm{H})-17, \mathrm{~T}(\mathrm{H}) 1$ and $\mathrm{T}(\mathrm{H}) 2$ cells. Nat Immunol. 2009;10(8):864-871.

19. Nomiyama T, et al. Osteopontin mediates obesityinduced adipose tissue macrophage infiltration and insulin resistance in mice. JClin Invest. 2007;117(10):2877-2888.

20. Molofsky AB, et al. Innate lymphoid type 2 cells sustain visceral adipose tissue eosinophils and alternatively activated macrophages. JExp Med. 2013;210(3):535-549.

21. Feuerer M, et al. Lean, but not obese, fat is enriched for a unique population of regulatory $\mathrm{T}$ cells that affect metabolic parameters. Nat Med. 2009;15(8):930-939.

22. Farber DL, Yudanin NA, Restifo NP. Human memory T cells: generation, compartmentalization and homeostasis. Nat Rev Immunol. 2014;14(1):24-35.

23. Nikolich-Zugich J. Ageing and life-long maintenance of $\mathrm{T}$-cell subsets in the face of latent persistent infections. Nat Rev Immunol. 2008;8(7):512-522.

24. Yokosuka T, Takamatsu M, Kobayashi-Imanishi W, Hashimoto-Tane A, Azuma M, Saito T. Programmed cell death 1 forms negative costimulatory microclusters that directly inhibit $\mathrm{T}$ cell receptor signaling by recruiting phosphatase SHP2. JExp Med. 2012;209(6):1201-1217.

25. Smith CA, et al. CD30 antigen, a marker for Hodgkin's lymphoma, is a receptor whose ligand defines an emerging family of cytokines with homology to TNF. Cell.1993;73(7):1349-1360.

26. Goronzy JJ, Li G, Yang Z, Weyand CM. The janus head of T cell aging - autoimmunity and immunodeficiency. Front Immunol. 2013;4:131.

27. Cinti S, et al. Adipocyte death defines macrophage localization and function in adipose tissue of obese mice and humans. JLipid Res. 2005;46(11):2347-2355.

28. Cai S, Lee CC, Kohwi-Shigematsu T. SATB1 packages densely looped, transcriptionally active chromatin for coordinated expression of cytokine genes. Nat Genet. 2006;38(11):1278-1288.

29. Alvarez JD, Yasui DH, Niida H, Joh T, Loh DY, Kohwi-Shigematsu T. The MAR-binding protein SATB1 orchestrates temporal and spatial expression of multiple genes during T-cell development. Genes Dev. 2000;14(5):521-535.

30. Johnson M. Corticosteroids: potential beta2agonist and anticholinergic interactions in chronic obstructive pulmonary disease. Proc Am Thorac Soc. 2005;2(4):320-5; discussion 340.

31. Tahir S, et al. A CD $153^{+} \mathrm{CD} 4^{+} \mathrm{T}$ follicular cell population with cell-senescence features plays a crucial role in lupus pathogenesis via osteopontin production. JImmunol. 2015;194(12):5725-5735.

32. Campisi J, d'Adda di Fagagna F. Cellular senescence: when bad things happen to good cells. Nat Rev Mol Cell Biol. 2007;8(9):729-740.

33. Lang R, Hammer M, Mages J. DUSP meet immu- 
nology: dual specificity MAPK phosphatases in control of the inflammatory response. J Immunol. 2006;177(11):7497-7504.

34. Byun HO, et al. Cathepsin D and eukaryotic translation elongation factor 1 as promising markers of cellular senescence. Cancer Res. 2009;69(11):4638-4647.

35. Latchman Y, et al. PD-L2 is a second ligand for PD-1 and inhibits T cell activation. Nat Immunol. 2001;2(3):261-268.

36. Keir ME, Francisco LM, Sharpe AH. PD-1 and its ligands in T-cell immunity. Curr Opin Immunol. 2007;19(3):309-314.

37. Freeman GJ, et al. Engagement of the PD-1 immunoinhibitory receptor by a novel $\mathrm{B} 7$ family member leads to negative regulation of lymphocyte activation. JExp Med. 2000;192(7):1027-1034.

38. Carter LL, et al. PD-1/PD-L1, but not PD-1/ PD-L2, interactions regulate the severity of experimental autoimmune encephalomyelitis. J Neuroimmunol. 2007;182(1-2):124-134.

39. Deng T, et al. Class II major histocompatibility complex plays an essential role in obesity-induced adipose inflammation. Cell Metab. 2013;17(3):411-422.

40. Kataoka K, Huh N. Application of a thermo-reversible gelation polymer, mebiol gel, for stem cell culture and regenerative medicine. JStem Cells Regen Med. 2010;6(1):10-14.
41. Murugaiyan G, Mittal A, Weiner HL. Increased osteopontin expression in dendritic cells amplifies IL-17 production by $\mathrm{CD} 4^{+} \mathrm{T}$ cells in experimental autoimmune encephalomyelitis and in multiple sclerosis. JImmunol. 2008;181(11):7480-7488.

42. Wolak T. Osteopontin - a multi-modal marker and mediator in atherosclerotic vascular disease. Atherosclerosis. 2014;236(2):327-337.

43. Stromnes IM, Goverman JM. Osteopontin-induced survival of T cells. Nat Immunol. 2007;8(1):19-20.

44. Lund SA, Giachelli CM, Scatena M. The role of osteopontin in inflammatory processes. JCell Commun Signal. 2009;3(3-4):311-322.

45. Kaleta B. Role of osteopontin in systemic lupus erythematosus. Arch Immunol Ther Exp (Warsz). 2014;62(6):475-482.

46. Shinohara ML, Jansson M, Hwang ES, Werneck MB, Glimcher LH, Cantor H. T-bet-dependent expression of osteopontin contributes to T cell polarization. Proc Natl Acad Sci U S A. 2005;102(47):17101-17106.

47. Stolarczyk E, et al. Improved insulin sensitivity despite increased visceral adiposity in mice deficient for the immune cell transcription factor T-bet. Cell Metab. 2013;17(4):520-533.

48. Yan X, et al. Plasma concentrations of osteopontin, but not thrombin-cleaved osteopontin, are associated with the presence and severity of nephropathy and coronary artery disease in patients with type 2 diabetes mellitus. Cardiovasc Diabetol. 2010;9:70.

49. Lancha A, et al. Osteopontin deletion prevents the development of obesity and hepatic steatosis via impaired adipose tissue matrix remodeling and reduced inflammation and fibrosis in adipose tissue and liver in mice. PLoS One. 2014;9(5):e98398.

50. Nishimura $S$, et al. Adipose natural regulatory $B$ cells negatively control adipose tissue inflammation. Cell Metab. 2013;18(5):759-766.

51. Stromnes IM, Goverman JM. Osteopontininduced survival of T cells. Nat Immunol. 2007;8(1):19-20.

52. Shimatani K, Nakashima Y, Hattori M, Hamazaki $\mathrm{Y}$, Minato N. PD-1+ memory phenotype $\mathrm{CD} 4^{+} \mathrm{T}$ cells expressing C/EBPalpha underlie $\mathrm{T}$ cell immunodepression in senescence and leukemia. Proc Natl Acad Sci U S A. 2009;106(37):15807-15812.

53. Gregor MF, Hotamisligil GS. Inflammatory mechanisms in obesity. Annu Rev Immunol. 2011;29:415-445.

54. Lumeng CN, Saltiel AR. Inflammatory links between obesity and metabolic disease. JClin Invest. 2011;121(6):2111-2117.

55. Versini M, Jeandel PY, Rosenthal E, Shoenfeld Y. Obesity in autoimmune diseases: not a passive bystander. Autoimmun Rev. 2014;13(9):981-1000. 